\title{
Geotechnical Properties of PARAHO Spent Shale
}

\author{
T. E. Gates
}

October 1982

Prepared for the U.S. Department of Energy under Contract DE-AC06-76RLO 1830

Pacific Northwest Laboratory Operated for the U.S. Department of Energy by Battelle Memorial Institute 


\title{
DISCLAIMER
}

This report was prepared as an account of work sponsored by an agency of the United States Government. Neither the United States Government nor any agency thereof, nor any of their employees, makes any warranty, express or implied, or assumes any legal liability or responsibility for the accuracy, completeness, or usefulness of any information, apparatus, product, or process disclosed, or represents that its use would not infringe privately owned rights. Reference herein to any specific commercial product, process, or service by trade name, trademark, manufacturer, or otherwise, does not necessarily constitute or imply its endorsement, recommendation, or favoring by the United States Government or any agency thereof. The views and opinions of authors expressed herein do not necessarily state or reflect those of the United States Government or any agency thereof.

\author{
PACIFIC NORTHWEST LABORATORY \\ operated by \\ BATTELLE \\ for the \\ UNITED STATES DEPARTMENT OF ENERGY \\ under Contract DE-AC06-76RLO 1830
}

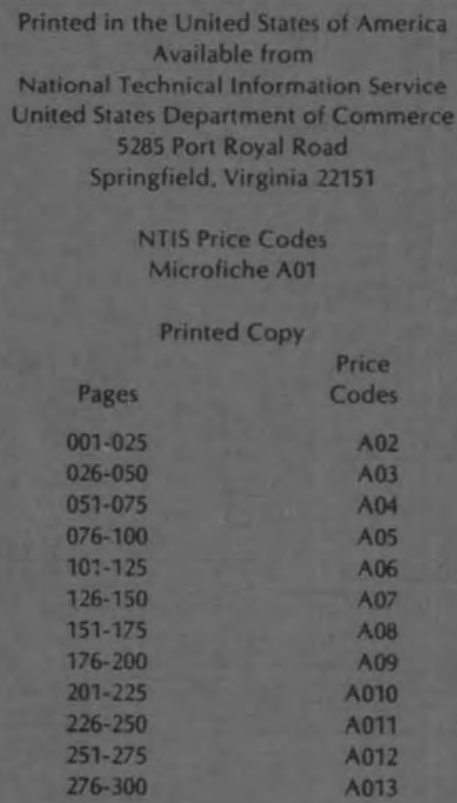


GEOTECHNICAL PROPERTIES OF PARAHO SPENT SHALE

T. E. Gates

October 1982

Prepared for the U.S. Department of Energy under Contract DE-AC06-76RLO 1830

Pacific Northwest Laboratory

Richland, Washington 99352 


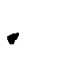




\section{ACKNOWLEDGMENTS}

This study was sponsored and supported by the Department of Energy under the Terrestrial Effects of $0 i 1$ Shale Program. The author gratefully acknowledges the suggestions provided by Ralph Franklin throughout the study as project administrator for DOE. The author al so expresses appreciation to Dr. Glendon Gee of Pacific Northwest Laboratory for his suggestions throughout the study. Special credit is due Wilbert Wakamiya (now with Aerojet GeneralEnvironment), Michael Dodson, and Paula Heller of the PNL Earth Sciences Section in conducting the laboratory work and providing the PARAHO oil shale geotechnical measurements. Special thanks are expressed to Ms. Darla Kennedy and Ms. Mary Heid who efficiently performed the word processing for this report. 
A literature review of available geotechnical properties for PARAHO retorted shale was conducted. Also reported are laboratory measurements made at PNL on key hydraulic properties of the PARAHO retorted shale. A determination and working knowledge of the geotechnical properties of the retorted oil shale are useful in considering the proposed options for efficient disposal of the spent shale in a structurally and environmentally safe manner.

The PARAHO retorted shale is classifed as a GP or GM soil depending on the amount of gravel present and the plasticity of the fines. Soils under these classifications indicate good compaction characteristics, good to excellent strength values, slight to medium compressibility, and overall a good foundation material.

The PARAHO material can be compacted in the laboratory to dry densities of $12.1 \mathrm{kN} / \mathrm{m}^{3}(77.0 \mathrm{pcf})^{(\mathrm{a})}$ to $17.0 \mathrm{kN} / \mathrm{m}^{3}(108.4 \mathrm{pcf})$ depending on compaction effort. Optimum water content for these densities range from 14.4 to 23.7 percent (dry weight), however, PARAHO $c$ an achieve high densities without requiring water for compaction. Vibration compaction is the best method of field compaction, with densities ranging from 98 to 110 percent of standard depending on the number of passes, lift thickness, and moisture content. Partic le breakage up to 28 percent occurs with PARAHO shale, depending on compactive effort.

The addition of small quantities of water causes bulking of the PARAHO materials and corresponding low densities. This, however, is common for materials of these gradations and this "bulking" effect does not occur for the better graded scalped and replaced materials.

Water retention characteristics indicate that optimum moisture contents ("field capacity") range from 13 to $14 \%$ (dry weight). Water contents in excess

(a) Numerical values al so may be expressed as mass per unit volume, where $N=$ $0.102 \mathrm{~kg}$; i.e., $9.8 \mathrm{kN} / \mathrm{m}^{3}=1 \mathrm{Mg} / \mathrm{m}^{3}$. 
of these values are likely to drain with time. In semi-arid climates it seems possible that a significant amount (up to 0.1 MT of water/MT of shale) of waste water could be deposited in the spent shale piles with little or no seepage. [Note: MT (metric ton)].

PARAHO shale can be considered as semipervious to pervious with permeability values of $10^{-3}$ to $10^{-4} \mathrm{~cm} / \mathrm{s}$, depending on compaction effort. Lower permeability values have been reported (Holtz 1976, Snethen et al. 1978) with values ranging from $10^{-6}$ to $10^{-7} \mathrm{~cm} / \mathrm{s}$ due to the greater amount of fines present. Large, but inconsistent, changes in permeability are observed with changes in compaction (void ratio). Additional study needs are indicated in this area.

PARAHO shale exhibits self-cementing characteristics. Under normal conditions cementing reactions are slow, with strength gains still indicated after 28 days. With its 3 to 8-fold strength gain and a design loading value of $572 \mathrm{kN} / \mathrm{m}^{2}$ ( $83 \mathrm{psi}$ ), based on a safety factor of 3 , PARAHO materials can be considered for construction of waste disposal dams and embankments. Inconsistent quality of the material would require careful considerations of its properties and variability for engineering design use, however.

The shear strength of PARAHO is comparable to similarly graded gravel with effective angles of internal friction, $\phi$, of 33 to 34 degrees. Depending on compactive effort and gradation of the material, effective cohesion values of $0.09 \mathrm{MN} / \mathrm{m}^{2}$ to $0.19 \mathrm{MN} / \mathrm{m}^{2}$ (128.05 psi to $277.45 \mathrm{psi}$ ) can be expected. Increased compaction effort does not noticeably improve PARAHO's shear strength parameters and generally exhibit positive pore pressures when sheared.

Drop height tests have been performed to determine densities achieved when processed oil shale is dropped from various conveyor heights. Major increase in density occurs within the initial $1.5 \mathrm{~m}(5 \mathrm{ft})$ of drop, from $10.3 \mathrm{kN} / \mathrm{m}^{3}$ to $12.5 \mathrm{kN} / \mathrm{m}^{3}(66.0 \mathrm{pcf}$ to $80.0 \mathrm{pcf})$. Only a small amount of additional densification can be achieved by increasing the drop height to $5.0 \mathrm{~m}(16.5 \mathrm{ft})$. 


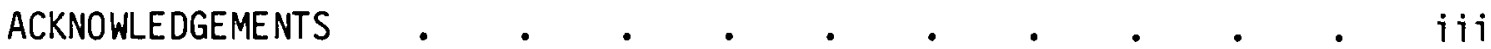

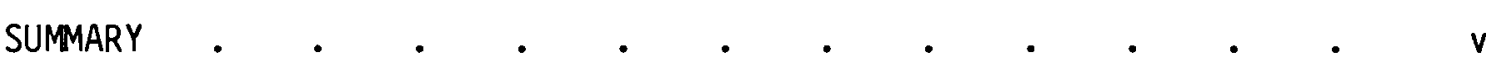

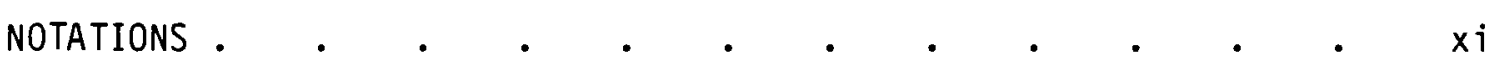

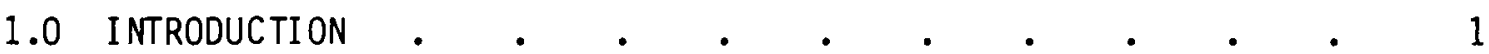

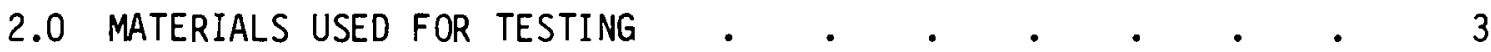

2.1 WATERWAY EXPERIMENT STATION (WES) $\quad$ • . . . . . $\quad$. 3

2.2 WOODWARD-CLYDE CONSULTANTS (WCC)

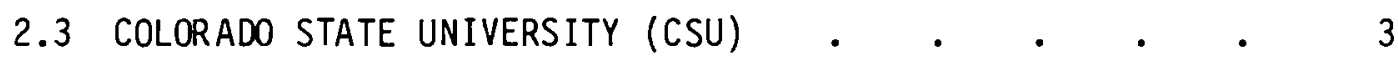

2.4 PACIFIC NORTHWEST LABORATORY (PNL) •

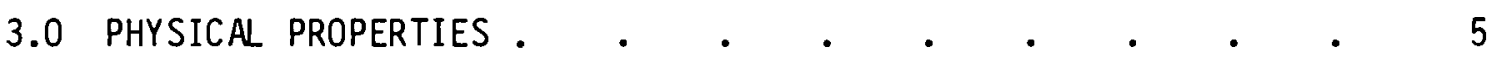

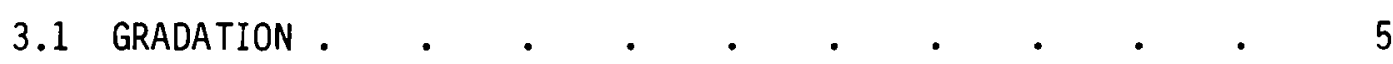

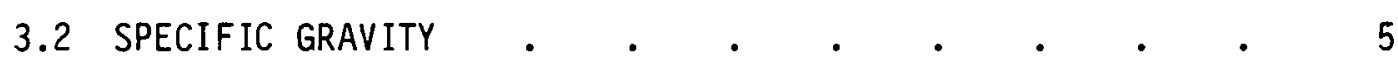

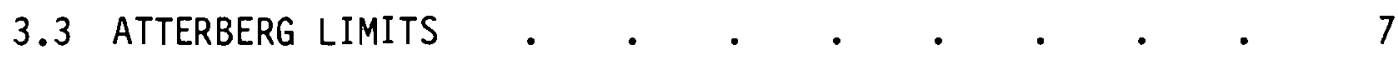

3.4 SOIL CLASSIFICATION

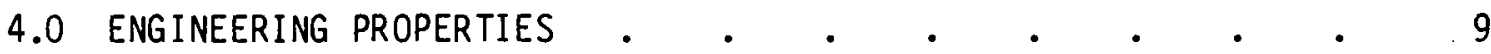

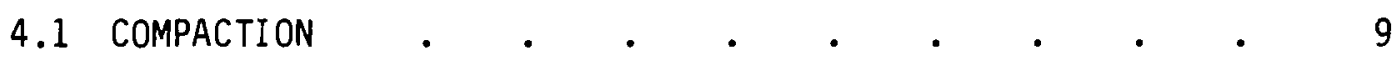

4.2 CONSOLIDATION

4.3 STRENGTH $. \quad . \quad . \quad . \quad . \quad . \quad . \quad . \quad . \quad . \quad . \quad . \quad 19$

4.3.1 Unconfined Compression Tests $\quad . \quad$. $\quad . \quad$. 19

4.3.2 Triaxial Compression Tests . . . . . . 23

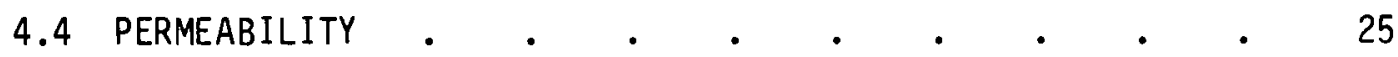

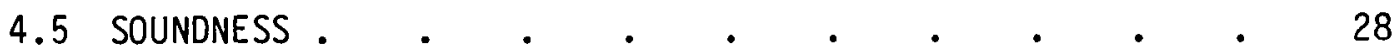




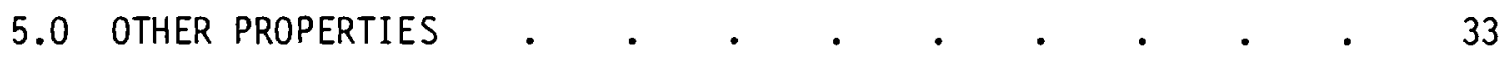

5.1 DROP HEIGHT TESTS . . . . . . . . . . . 33

5.2 WATER RETENTION CHARACTERISTICS $\quad . \quad \ldots \quad$. $\quad$. 33

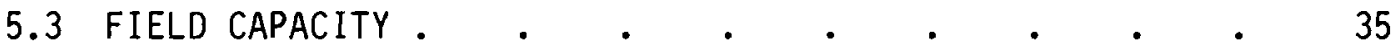

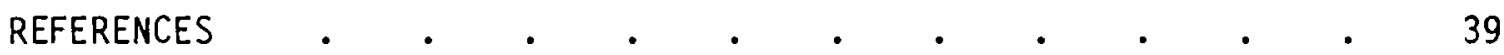

viji 
FIGURES

3.1 Comparison of Raw and Retorted 0il Shale Gradation a $\quad 6$

3.2 Comparison of Gradation Analyses for PARAHO Retorted

0il Shale.

4.1 Water Content-Density Relationship for $30.5 \mathrm{~cm}$ (12 in.) dia

Compaction Test on PARAHO Retorted 0 il Shale. . . .

4.2 Water Content-Density Relationship for $15 \mathrm{~cm}$ ( 6 in.) dia Compaction Test on Modeled PARAHO Retorted Oil Shale

4.3 Effects of Compaction Effort on Gradation for $30.5 \mathrm{~cm}$

(12 in.) dia Compaction Tests on PARAHO Retorted $0 i 1$

4.4 Effects of Compaction Effort on Gradation for $15 \mathrm{~cm}$ ( 6 in.) dia Compaction Tests on PARAHO Retorted 0 il Shale

4.5 PARAHO Shale Particle Size Distribution After Compaction

4.6 Effect of Curing Time on the Unconfined Compressive Strength for Compacted PARAHO . . . . . . . 20

4.7 Total and Effective Stress Envelopes for PARAHO Compacted to Standard Effort Density

4.8 Effective Stress Envelope for PARAHO Compacted to Modified Effort Density . . . . . . . .

4.9 Permeability-Void Ratio Relationships for Compacted PARAHO Retorted 0il Shale $. \quad . \quad . \quad . \quad . \quad . \quad . \quad 29$

4.10 Permeability Values for Full Size PARAHO Material . . 30

5.1 Effect of Drop Height on Dry Density for PARAHO and TOSCO Retorted 0 il Shales. . . . . . . . 34

5.2 Water Retention PARAHO Shale "Loose Pack" . . . . . 37

5.3 Water Retention PARAHO Shale "Tight Pack" . . . . . 38 
3.1 Summary of Atterberg Limits for PARAHO Shale . . . . 8

4.1 Summary of Compaction Test Results on PARAHO 0 il Shale . $\quad 12$

4.2 Comparison of Compaction Results on PARAHO $\quad$. . . . . $\quad$ - 13

4.3 Breakage Factors Due to Compaction of PARAHO Material . $\quad 17$

4.4 Percent Settlement Versus Applied Load for Retorted PARAHO Shale $. \quad . \quad . \quad . \quad . \quad . \quad . \quad . \quad . \quad . \quad 18$

4.5 Summary of Unconfined Test Results on PARAHO Oil Shale . $\quad 21$

4.6 Summary of Consolidated-Drained $(S)$ and -Undrained $(\bar{R})$ Triaxial Compression Tests on PARAHO Material. . . $\quad 24$

4.7 Permeability of PARAHO Shale at Different Dry Bulk Densities . . • . . . . . . . . 31

4.8 Summary of Los Angeles Abrasion Test Results on PARAHO Shale $. \quad . \quad . \quad . \quad . \quad . \quad . \quad . \quad . \quad . \quad 31$

5.1 Summary of Drop Height Tests on PARAHO Shale . . . . . 33

5.2 Water Retention Characteristics by Large Column . . $\quad 35$

5.3 Water Retention Characteristics by Pressure Plate Extractor . • • • • • • • • . . 36 


\section{NOTATIONS}

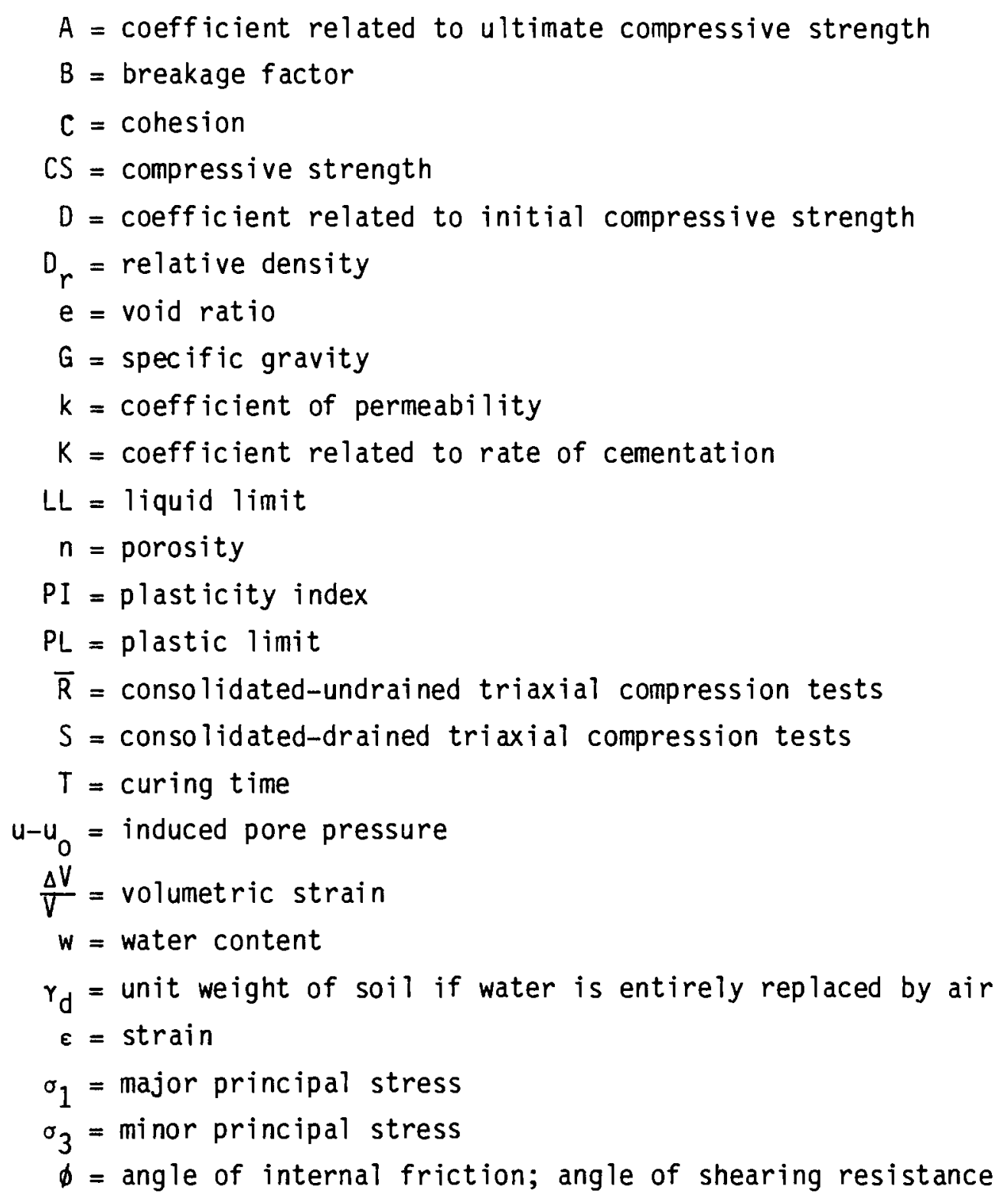




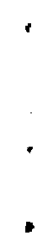




\subsection{INTRODUCTION}

0 il shale is a sedimentary rock containing kerogen. When heated the kerogen decomposes to yield oil. The principle concentration of oil shale in the United States is the Green River Formation, located in the three states of Colorado, Wyoming, and Utah. Of the total $64,750 \mathrm{~km}^{2}\left(25,000 \mathrm{mi}^{2}\right)$ of oil shale in the Green River Formation, approximately $44,030 \mathrm{~km}^{2}\left(17,000 \mathrm{mi}^{2}\right)$ are estimated to contain oil shale suitable for commercial development.

One of the major problems inherent to commercial oil shale production is the efficient and safe disposal of 80 to 85 percent of the total raw weight after retorting. To date several options have been proposed for the disposal of retorted oil shales, some of these being:

1. backfilling the mine with spent shale as the raw shale is removed;

2. filling deep narrow canyons of the oil shale mine area with the spent shale; and

3. using the spent shale for productive uses, such as material for road bases, waste disposal dams, and embankments.

The options require a determination and working knowledge of the geotechnical properties of the retorted oil shale for efficient disposal in a structurally and environmentally safe manner.

The processing method will determine the majority of the key geotechnical parameters. Currently, there are several retorting processes in various stages of development. These include the Chevron, Lurgi, Occidental, PARAHO, TOSCO, and others. Occidental is largely an in situ process with some above ground retorting, where the other processes listed completely utilize above ground retorting methods. The various processes can utilize fine or coarse materials, low or high temperatures, and direct or indirect heat mode producing different types of retorted shale.

The report is primarily a review of available geotechnical properties for PARAHO retorted shale reported in the literature, but also includes laboratory measurements made at PNL. The PARAHO internal combustion process is one of the simplest processes, utilizing gravity feed through a vertical retort 
operating at about $649^{\circ} \mathrm{C}\left(1200^{\circ} \mathrm{F}\right)$ in the direct heat mode. The raw shale is crushed to about $6 \mathrm{~cm}(21 / 2 \mathrm{in.})$ maximum size, with the minus $9 \mathrm{~mm}(3 / 8 \mathrm{in.})$ fines removed and presently discarded.

The following section presents the materials used for testing by the various institutes. This is an important consideration since ASTM specifications limits the maximum size of the large fraction used in many tests, which could effect the resulting data.

Section 3.0 presents the physical properties of PARAHO material. Of interest to geotechnical engineers for classification and comparison purposes are gradation, specific gravity, and Atterberg limits.

Engineering properties needed for design considerations include compaction, consolidation, strength, permeability, and soundness which are discussed in Section 4.0. Section 5.0 presents properties not specifically covered under Sections 3.0 or 4.0 . 


\subsection{MATERIALS USED FOR TESTING}

The PARAHO materials used in the testing needs to be considered in the comparison of results. Description of the sampling materials used for testing by the various institutes are provided below.

\subsection{WATERWAY EXPERIMENT STATION (WES)}

The PARAHO material was processed by passing the material through a Trommel rotating drum screen into various sieve sizes. The stored fractions were reconstituted for test specimens using the gradation determined by hand sieving. This gradation (Figure 3.2) was selected as representing the gradation of PARAHO material as it leaves the retort.

The reconstituted fractions consisted of two groups: 1) full-scale material, and 2) scalped and replaced. In the full-scale group fractions $8 \mathrm{~cm}$ ( 3 in.) and below were reconstituted based on the gradation determined by hand sieving. Specifications limit the maximum particle diameter to one fourth to one sixth of the corresponding mold diameter, hence, the larger particles must be scalped and replaced with an equal weight of finer material. This constituted the Group 2 material.

\subsection{WOODWARD-CLYDE CONSULTANTS (WCC)}

The PARAHO material passed the $8 \mathrm{~cm}$ ( 3 in.) screen with 96 to 98 percent passing the $4 \mathrm{~cm}$ ( $11 / 2 \mathrm{in.})$ screen. The plus $4 \mathrm{~cm}(11 / 2 \mathrm{in.})$ material was not used in the laboratory tests. Due to the small amount of this material to the total, it was felt that insignificant change on the properties would result.

\subsection{COLORADO STATE UNIVERSITY (CSU)}

The experimental approach was designed to simulate the operating conditions from a modeled sense. The initial raw oil shale was crushed to minus $4 \mathrm{~cm}$ ( $11 / 2$ in.) to represent the $8 \mathrm{~cm}$ ( 3 in.) commercial shale size. All tests were conducted using this "modeled" material after retorting. 


\subsection{PACIFIC NORTHWEST LABORATORY (PNL)}

The PARAHO material was processed, using a Ro-Tap mechanical shaker, by passing the material through various sieve sizes. To assure uniformity between test specimens the fractions were reconstituted using the average percentage retained, during processing, for each respective sieve size. Full size material was used during reconstitution of the fractions. 


\subsection{PHYSICAL PROPERTIES}

Gradation, specific gravity, and Atterberg limits are physical properties of interest to geotechnical engineers. From these physical properties, comparisons may be made with other soils exhibiting similar characteristics and expected behavior predicted. Not considered to be a physical property, but of equal importance, is the classification of the material.

\subsection{GRADATION}

Since the gradation of retorted shale is dependent on mining operation, type of crusher, and amount of crushing the material undergoes prior to retorting, gradation is highly variable. The gradation of retorted shale is, however, helpful in classifying the material and indicating its suitability for engineering purposes. The influence of the retorting process on gradation is evident in Figure 3.1.

Figure 3.2 presents the results of the gradation analysis performed by WES (Townsend and Peterson 1979) on PARAHO material, plus those determined by WCC (Holtz 1976). Comparison between the hand-sieved and Gibson shaker-sieved gradation results (WES) show that the PARAHO material is friable and experiences some breakdown by the shaker, producing approximately 10 percent more fines.

Comparison of the gradations determined by WES with those of WCC show fairly close agreement in one case and a finer gradation obtained by WCC for another (Townsend and Peterson 1979). The agreement shown in Figure 3.2 is representative of the gradation of PARAHO retored shale considering the variability of oil shale and gradations entering the retort.

\subsection{SPECIFIC GRAVITY}

The specific gravity may be expressed in three forms (Snethen et al. 1978, Townsend and Peterson 1979):

1. the specific gravity of solids, which is applied to soils finer than a No. 4 sieve;

2. the apparent specific gravity; and

3. the bulk or mass specific gravity. 
U.S. STANDARD SIEVE NUMBERS

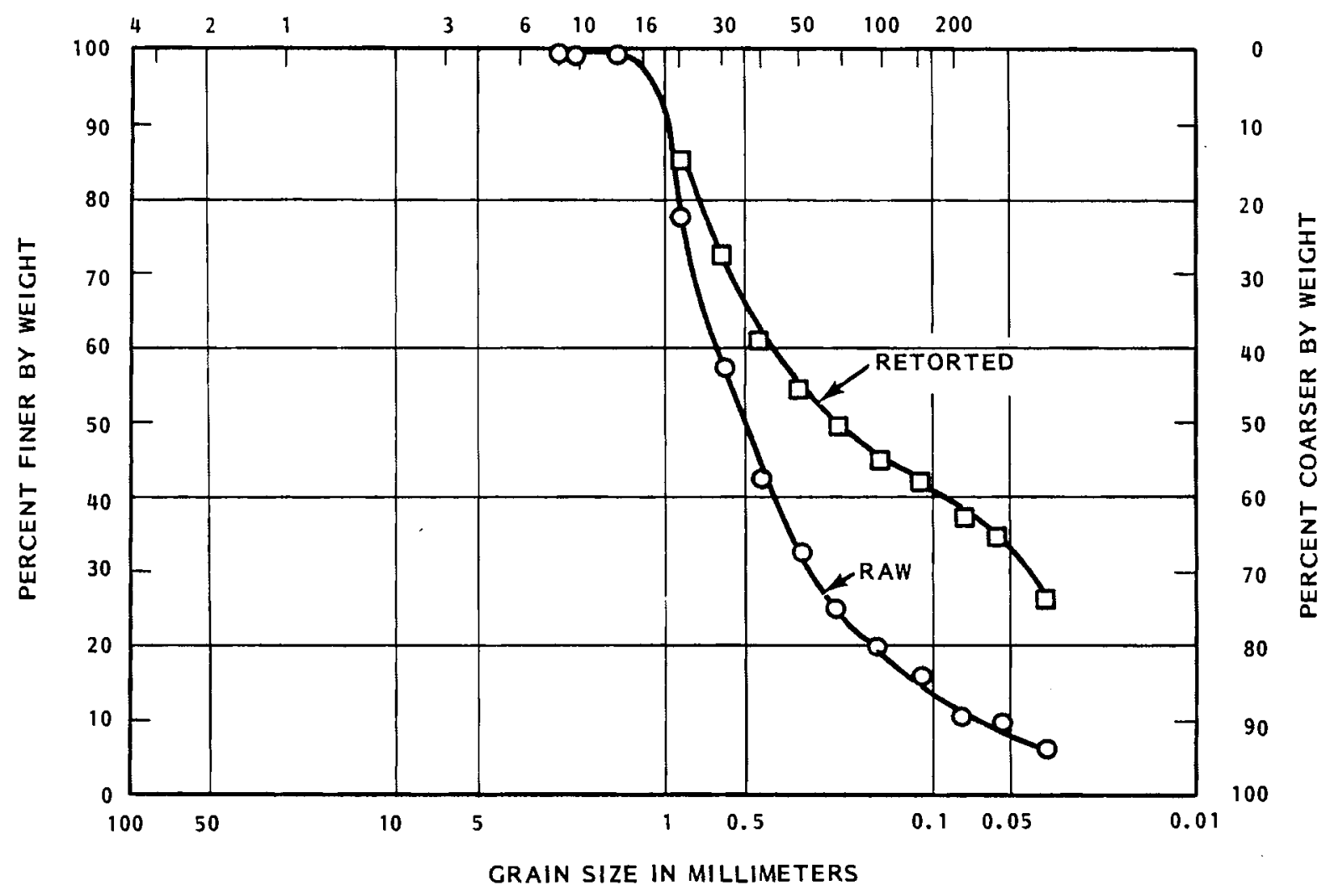

FIGURE 3.1. Comparison of Raw and Retorted 0il Shale Gradation. Based on all material less than $2 \mathrm{~mm}$ (Townsend and Peterson 1979)

The apparent and mass specific gravities are both applied to soils coarser than the No. 4 sieve. The apparent specific gravity is routinely used when dealing with coarse aggregates.

Snethen et al. (1978) reported that the majority of apparent specific gravities for PARAHO material varied from 2.52 to 2.59. The apparent specific gravity of the PARAHO material used by WES and WCC was determined to be 2.42 and 2.54 , respectively.

Mass specific gravity (relative bulk density) for PARAHO material range between 1.80 and 1.85, and specific gravity of solids around 2.67.

In comparison with sandstone, limestone, basalt, and granite rockfill materials with values ranging from 2.65 to 2.87 for apparent specif ic gravity and 2.29 to 2.84 for mass specific gravity, the specific gravity values of PARAHO material are quite low. 
U.S. STANDARD SIEVE NUMBERS

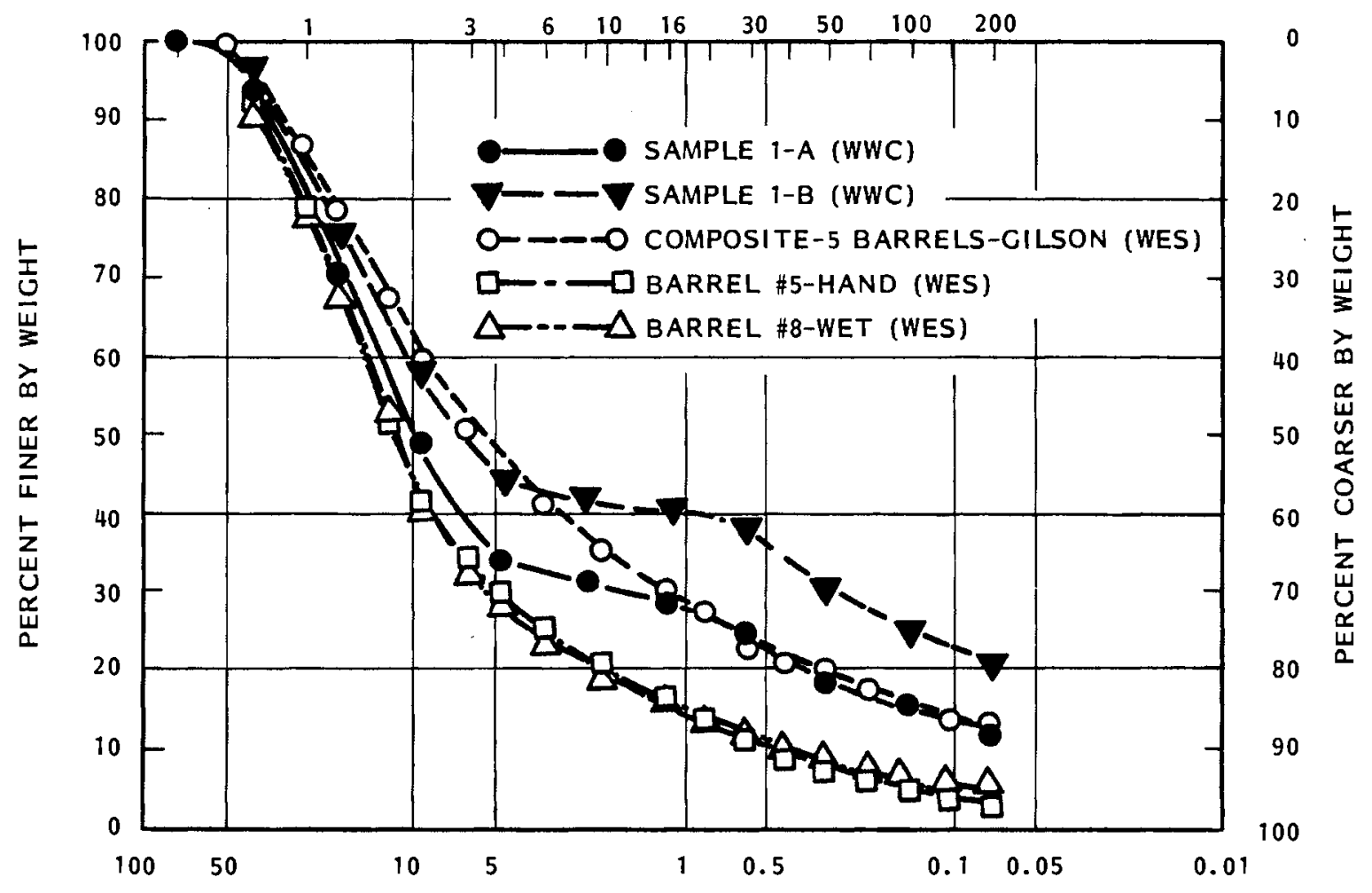

GRAIN SIZE IN MILLIMETERS

FIGURE 3.2. Comparison of Gradation Analyses for PARAHO Retorted 0 il Shale (Townsend and Peterson 1979)

\subsection{ATTERBERG LIMITS}

The Atterberg limit tests determine, for fine-grained soils, the water contents at the boundaries between liquid, plastic, semisolid, and solid states. The plasticity index (PI), the difference between liquid and plastic limits, and liquid limit can be used to characterize mechanical properties of soil particles. The lower the plasticity index at a given liquid limit, the more likely it is that organic material is present and the greater the permeability and compressibility.

Summarized below are results of Atterberg limit tests conducted on PARAHO material by WES. WCC (Holtz 1976) listed PI values of 3 percent for PARAHO, which agree well with the results in Table 3.1 . 
TABLE 3.1. Summary of Atterberg Limits for PARAHO Shale (Townsend and Peterson 1979)

\begin{tabular}{|c|c|c|c|c|}
\hline $\begin{array}{l}\text { Fraction } \\
\text { Number } \\
\end{array}$ & $\underline{L L} \underline{L}^{(a)}$ & $P L^{(a)}$ & $\underline{P I}^{(a)}$ & Remarks \\
\hline-40 & 29 & 29 & $N P^{(b)}$ & Blenderized \\
\hline-40 & 32 & 28 & 4 & Blenderized, 9 mo. soak \\
\hline-40 & 37 & 32 & 5 & Blenderized, 18 mo. soak \\
\hline
\end{tabular}

(a) $L L, P L$, and $P I=1 i q u i d ~ l i m i t$, plastic limit, and plasticity index, respectively.

(b) $N P=$ nonplastic

The increase in PI values from nonplastic to 5 percent after 18 months of inundation indicates that some breakdown and softening can occur with weathering of the shale.

\subsection{SOIL CLASSIFICATION}

The retorted PARAHO shales, as sampled, would be classified as a GP or GM soil under the Unified $\mathrm{Cl}$ assification System depending on the amount of gravel present and the plasticity of the fines. Soils in the GP group are poorly graded gravels and sands containing less than $5 \%$ of nonplastic fines.

In general, soils in the GM group include gravels or sands which contain more than $12 \%$ of fines having little or no plasticity. Gradation is not important, with both well graded and poorly graded materials included. Some soils and gravels in this group may have a binder composed of natural cementing agents, thus the dry strength is provided by a small amount of soil binder or by cementation of calcareous material or iron oxide. The fine fraction of noncemented materials may be composed of silts or rock-flour types having little or no plasticity, and the mixture will exhibit no dry strength.

It may be concluded that, in general, soils under these classifications indicate good compaction characteristics, good to excellent strength values, slight to medium compressibility, and overall a good foundation material. 


\subsection{ENGINEERING PROPERTIES}

The major engineering properties pertinent to geotechnical engineers for the determination of an efficient disposal method for retorted oil shale in a structurally and environmentally safe manner are compaction, consolidation, strength, permeability, and soundness.

\subsection{COMPACTION}

Numerous laboratory compaction tests have been performed to evaluate the compaction characteristics of PARAHO material due to the importance of compaction in disposing of spent shale. Snethen et al. (1978) summarized the variability in compaction characteristics for this material in the following tabulation.

\begin{tabular}{|c|c|c|c|}
\hline $\begin{array}{l}\text { Compaction Energy } \\
\mathrm{kN} / \mathrm{m}^{2} \text { (psf) } \\
\end{array}$ & $\begin{array}{c}\text { ASTM } \\
\text { Standard } \\
\end{array}$ & $\begin{array}{l}\text { Optimum Water } \\
\text { Content w, } \% \\
\end{array}$ & $\begin{array}{l}\text { Maximum Dry Density } \\
r_{d}{ }_{m a x} \mathrm{kN} / \mathrm{m}^{3} \text { (pcf) }\end{array}$ \\
\hline $297(6,200)$ & $50 \quad 0698$ & $18.5-23.7$ & $12.1-15.6(77.0-99.2)$ \\
\hline $\begin{array}{c}592(12,375) \\
\text { Standard }\end{array}$ & D698 & $15.5-22.0$ & $12.6-16.2(80.2-103.2)$ \\
\hline $\begin{array}{l}2,693(56,250) \\
\text { Modif ied }\end{array}$ & D1557 & $14.4-22.0$ & $13.9-17.0(88.8-108.4)$ \\
\hline
\end{tabular}

These variations are largely attributed to differences in retorting mode, variability of the unprocessed shale, gradation, and particularly the amount of fines.

Shown in Figure 4.1 are results of large scale [30.5 cm (12 in.) dia] compaction tests using 60 percent of standard, standard, and modified compactive efforts on minus $5 \mathrm{~cm}$ ( 2 in.) dia PARAHO material performed by WES. Companion tests performed on scalped and replaced minus $2 \mathrm{~cm}$ ( $3 / 4 \mathrm{in.}$ ) material using a $15 \mathrm{~cm}$ (6 in.) dia mold are shown in Figure 4.2. Using a $28 \mathrm{~cm}$ (11 in.) dia mold, vibrating table method maximum-minimum density tests were also performed on minus $5 \mathrm{~cm}$ ( 2 in.) and minus $2 \mathrm{~cm}$ (3/4 in.) dia material. Table 4.1 presents a summary of the compaction test data. 


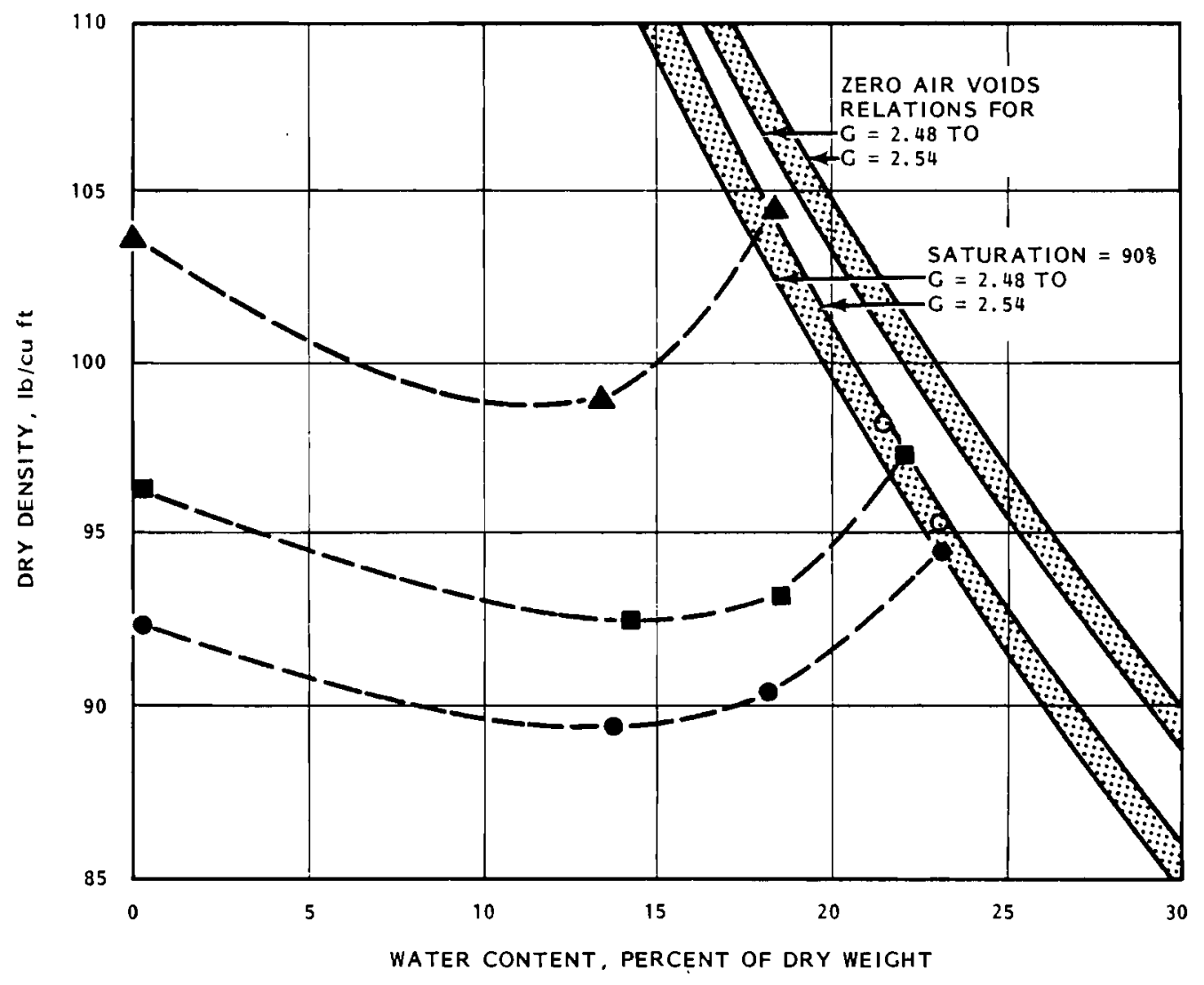

\begin{tabular}{|c|c|c|c|c|c|c|c|c|}
\hline $\begin{array}{l}\text { SAMPLE } \\
\text { NO. }\end{array}$ & $\begin{array}{l}\text { ELEV OR } \\
\text { DEPTH }\end{array}$ & \multicolumn{2}{|c|}{ CLASSIFICATION } & c & LL & PL & $\begin{array}{l}\text { है> } \\
\mathrm{NO} .4 \\
\end{array}$ & $\begin{array}{l}8> \\
3 / 4 \mathrm{in} .\end{array}$ \\
\hline & & \multicolumn{2}{|c|}{ "AS BATCHED" } & 2.48 & & NP & 72.5 & 33.5 \\
\hline 0 & & \multicolumn{2}{|c|}{$60 \%$ STANDARD EFFORT } & 2.51 & & NP & 63.0 & 28.5 \\
\hline$\square$ & & \multicolumn{2}{|c|}{ STANDARD EFFORT } & 2.52 & & NP & 58.0 & 25.5 \\
\hline$\Delta$ & & \multicolumn{2}{|c|}{ MODIFIED EFFORT } & 2.54 & & NP & 49.0 & 19.5 \\
\hline \multicolumn{9}{|c|}{ SAMPLE NO. } \\
\hline \multicolumn{9}{|c|}{ NATURAL WATER CONTENT, PERCENT } \\
\hline \multicolumn{9}{|c|}{ OPTIMUM WATER CONTENT, PERCENT } \\
\hline \multicolumn{9}{|c|}{ MAX DRY DENSITY, $\mathrm{lb} / \mathrm{cu} \mathrm{ft}$} \\
\hline \multicolumn{4}{|c|}{ REMARKS $C_{5}=2.67$} & \multicolumn{5}{|c|}{ OIL SHALE (PARAHO) } \\
\hline$G_{a}=2.42$ NOTE: COULD NOT & NOTE : & OULD NOT & \multicolumn{6}{|c|}{ 12-in. -DIAM COMPACTION TESTS } \\
\hline \multicolumn{3}{|c|}{ COMPACT MODIFIED EFFORT } & \multicolumn{6}{|l|}{ AREA } \\
\hline \multicolumn{3}{|c|}{ SAMPLE $\mathbf{w}=23 \%$} & \multicolumn{3}{|c|}{ BORING NO. } & DATE & MARCH & 1977 \\
\hline \multicolumn{3}{|c|}{ * FREE WATER } & \multicolumn{6}{|c|}{ COMPACTION TEST REPORT } \\
\hline
\end{tabular}

FIGURE 4.1. Water Content-Density Relationship for $30.5 \mathrm{~cm}$ (12 in.) dia Compaction Test on PARAHO Retorted $0 i l$ Shale (Townsend and Peterson 1979) 


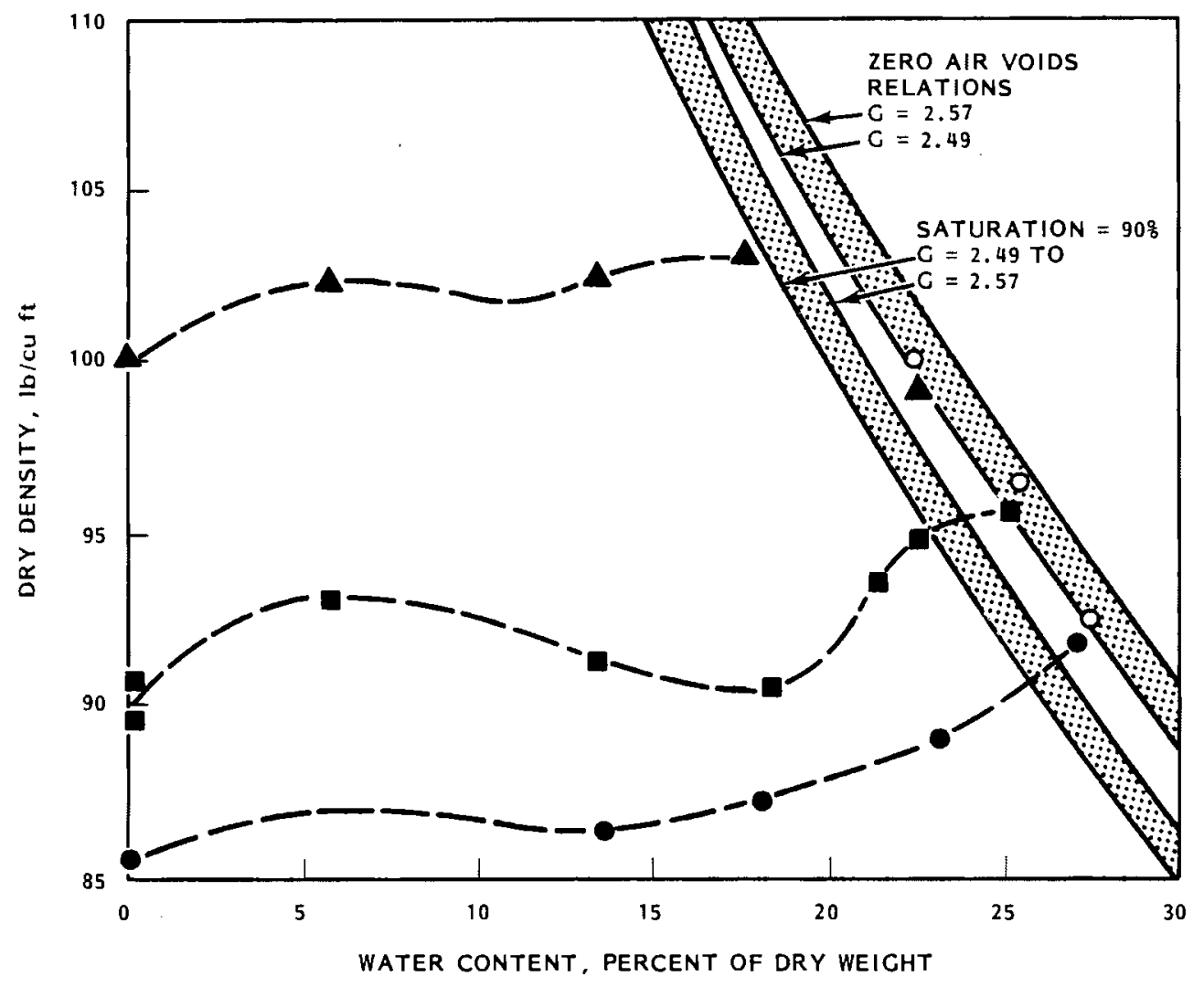

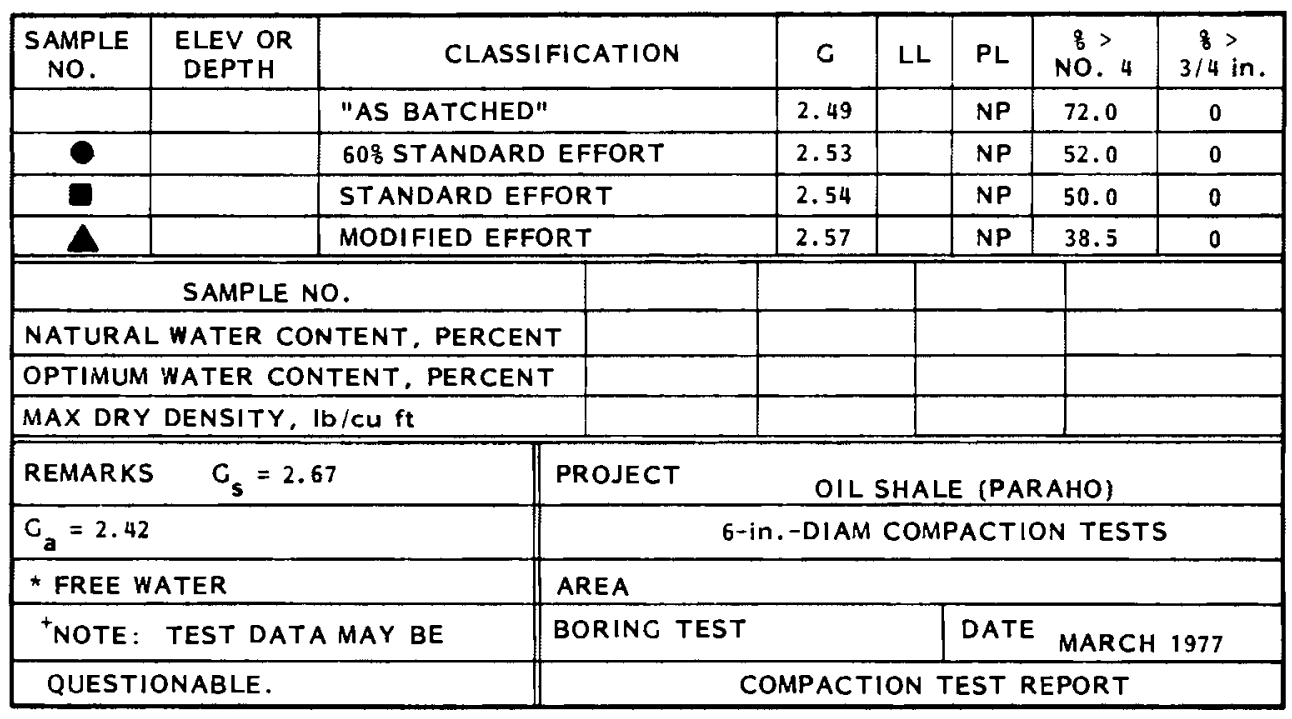

FIGURE 4.2. Water Content-Density Relationships for $15 \mathrm{~cm}$ (6 in.) dia Compaction Tests on Modeled PARAHO Retorted 0 il Shale (Townsend and Peterson 1979) 
TABLE 4.1. Summary of Compaction Test Results on PARAHO 0 il Shale (Townsend and Peterson 1979)

\begin{tabular}{|c|c|c|c|c|c|}
\hline Gradation Size & $\begin{array}{c}\text { Compaction } \\
\text { Effort } \\
\end{array}$ & $\begin{array}{c}\text { Maximum } \\
\text { Dry } \\
\text { Density } \\
r_{d_{\max }} \\
\text { pcf } \\
\end{array}$ & $\begin{array}{c}\text { Minimum } \\
\text { Dry } \\
\text { Density } \\
{ }^{Y_{d}}{ }_{\text {min }} \\
\text { pcf } \\
\end{array}$ & $\begin{array}{c}\text { Water } \\
\text { Content } \\
\text { w, \% } \\
\end{array}$ & $\begin{array}{l}\text { Relative } \\
\text { Density } \\
\text { D } r=\% \\
\end{array}$ \\
\hline \multirow[t]{2}{*}{$\begin{array}{l}\text { Original } \\
(-2 \text { in. fraction })\end{array}$} & $\begin{array}{l}\text { Vibration } \\
60 \% \text { of } \\
\text { standard }\end{array}$ & $\begin{array}{l}89.2 \\
94.6\end{array}$ & 66.0 & $\overline{23.3}$ & $\overline{116.2}$ \\
\hline & $\begin{array}{l}\text { Standard } \\
\text { Modif ied }\end{array}$ & $\begin{array}{r}97.5 \\
104.4\end{array}$ & - & $\begin{array}{l}22.2 \\
18.4\end{array}$ & $\begin{array}{l}124.2 \\
141.4\end{array}$ \\
\hline \multirow[t]{2}{*}{$\begin{array}{l}\text { Scalped and } \\
\text { replaced } \\
(-3 / 4 \text { in. fraction })\end{array}$} & $\begin{array}{l}\text { Vibration } \\
60 \% \text { of } \\
\text { standard }\end{array}$ & $\begin{array}{l}81.8 \\
91.9\end{array}$ & 62.9 & $\overline{27.2}$ & $\overline{136.6}$ \\
\hline & $\begin{array}{l}\text { Standard } \\
\text { Modif ied }\end{array}$ & $\begin{array}{r}95.7 \\
103.1\end{array}$ & - & $\begin{array}{l}25.2 \\
17.7\end{array}$ & $\begin{array}{l}148.3 \\
168.8\end{array}$ \\
\hline $\begin{array}{l}\text { Parallel }(-3 / 4 \text { in. } \\
\text { fraction })\end{array}$ & Standard & $\begin{array}{l}88.9 \\
88.0\end{array}$ & & $\begin{array}{r}0.2 \\
22.8\end{array}$ & \\
\hline $\begin{array}{l}\text { Scalped }(-3 / 4 \text { in. } \\
\text { fraction) }\end{array}$ & Standard & $\begin{array}{l}88.7 \\
92.5\end{array}$ & & $\begin{array}{r}0.2 \\
23.1\end{array}$ & \\
\hline
\end{tabular}

The results presented in Figures 4.1 and 4.2 indicate that both full scale and scalped and replaced materials produced significantly higher densities with increased compaction effort. A comparison of results in Table 4.1 also shows that the scalping and replacement procedure underestimates the maximum dry density and overestimates the optimum water content. 0thers have also observed that scalping and replacement modeling fails to achieve results comparable to full scale (Snethen et al. 1978).

Table 4.2 compares results between the WES and WCC study. These comparisons show that the material tested at WES produced greater densities due to its greater amount of coarse particles for both the minus $5 \mathrm{~cm}$ ( 2 in.) and minus $2 \mathrm{~cm}$ ( $3 / 4$ in.) gradations than did the finer grained wCC minus $4 \mathrm{~cm}$ (1 $1 / 2$ in.) and minus $2 \mathrm{~cm}$ ( $3 / 4$ in.) gradations. 
TABLE 4.2. Comparison of Compaction Results on PARAHO (Townsend and Peterson 1979)

\begin{tabular}{|c|c|c|c|c|c|c|c|c|c|c|c|c|}
\hline \multirow[b]{2}{*}{$\begin{array}{c}\text { Compaction Effort } \\
f t-1 b / \mathrm{ft}^{3} \\
\end{array}$} & \multicolumn{3}{|c|}{$\begin{array}{c}\text { WES } \\
-2 \text { in. Material } \\
\text { Breakage }\end{array}$} & \multicolumn{3}{|c|}{$\begin{array}{l}\text { WCC } \\
2 \text { in. Material } \\
\text { Breakage } \\
\end{array}$} & \multicolumn{3}{|c|}{$\begin{array}{c}\text { WES } \\
-3 / 4 \text { in. M }\end{array}$} & $-3 / 4$ & $\begin{array}{l}\text { ICC } \\
\text { n. Mat } \\
\text { reakag }\end{array}$ & ial \\
\hline & $\begin{array}{c}w_{o p t}(a) \\
\% \\
\end{array}$ & $\begin{array}{l}\gamma_{d_{\max }} \\
\text { pcf } \\
\end{array}$ & B & $\begin{array}{c}w_{\text {opt }} \\
\% \\
\end{array}$ & $\begin{array}{l}{ }_{d_{\text {max }}} \\
\text { pcf }\end{array}$ & B & $\begin{array}{c}w_{\text {opt }} \\
\% \\
\end{array}$ & $\begin{array}{l}\gamma_{d_{\max }} \\
\text { pcf } \\
\end{array}$ & $\underline{B}$ & $\begin{array}{c}w_{\mathrm{opt}} \\
\% \\
\end{array}$ & $\begin{array}{r}\gamma_{d_{\max }} \\
\text { pcf }\end{array}$ & B \\
\hline $\begin{array}{l}6,200 \text { (b) } 9 r \\
7,425 \text { (c) }(50 \% \text { or } \\
60 \% \text { of standard) }\end{array}$ & 23.3 & 94.6 & 11 & 22 & 87.5 & 19 & 27.2 & 91.9 & 20 & 27.2 & 85.5 & 10 \\
\hline $\begin{array}{l}12,375 \\
\text { (st and ard) }\end{array}$ & 22.2 & 97.5 & 16 & 22 & 94.8 & 22 & 25.3 & 95.7 & 24 & 25.2 & 90.2 & 17 \\
\hline $\begin{array}{l}56,250 \\
\text { (modif ied) }\end{array}$ & 18.4 & 104.4 & 25 & 22 & 98.9 & 25 & 17.7 & 103.1 & 34 & 22.0 & 96.4 & 20 \\
\hline
\end{tabular}

\footnotetext{
(a) wopt $_{\text {(b) opt imum water content }}$

(c) WES
} 
The extent of particle breakage during compaction for tests performed by WES on full scaled and scalped and replaced gradations of PARAHO material are shown in Figures 4.3 and 4.4 , respectively. Little difference in the magnitude of particle breakage exists for 60 percent of standard and standard compaction effort. Considerable breakage occurs, however, when modified effort is applied. Table 4.3 summarizes the breakage factor $B$, for the full scale and scalped and replaced compaction tests. These $B$ values show a progressive increase with compaction effort.

Similar results were obtained by PNL where full scale compaction tests, using a $15 \mathrm{~cm}$ ( 6 in.) dia mold, were performed under standard, 50 percent modified, and modified compaction effort. Sieve analyses were performed after each compaction test and the results are summarized in Figure 4.5.

For materials containing less than 12 percent fines ASTM criteria recommend using a vibratory table method to obtain the maximum dry density. The maximum dry density achieved by vibration was only 14.0 and $12.8 \mathrm{kN} / \mathrm{m}^{3}(89.2$ and $81.8 \mathrm{pcf}$ ) for full scale and scalped and replaced gradations, respectively, for the WES "as batched" gradations containing only 3 percent fines. These results are considerably lower than the maximum dry density achieved by 60 percent of standard compaction effort shown in Table 4.1 .

WCC also presented results showing that vibratory densification produced lower densities than those achieved by impact compaction. Hence, it might be concluded that retorted PARAHO shale does not respond favorably to vibratory compaction. This, however, is contrary to field compaction test which showed that the most economical compaction of PARAHO material could be obtained using a vibratory drum roller (Holtz 1976, Snethen et al. 1978).

\subsection{CONSOLIDATION}

Settlement properties are very important in assessing the stability of an embankment constructed of retorted shales. Further, the total volume required in a disposal site, its permeability, and strength characteristics are influenced by consolidation of retorted shale.

Snethen et al. (1978) reported settlement properties on retored shale. Summarized in Table 4.4 are the percent settlement for the various applied loads (ASTM D698 energy). 
U.S. STANDARD SIEVE NUMBERS

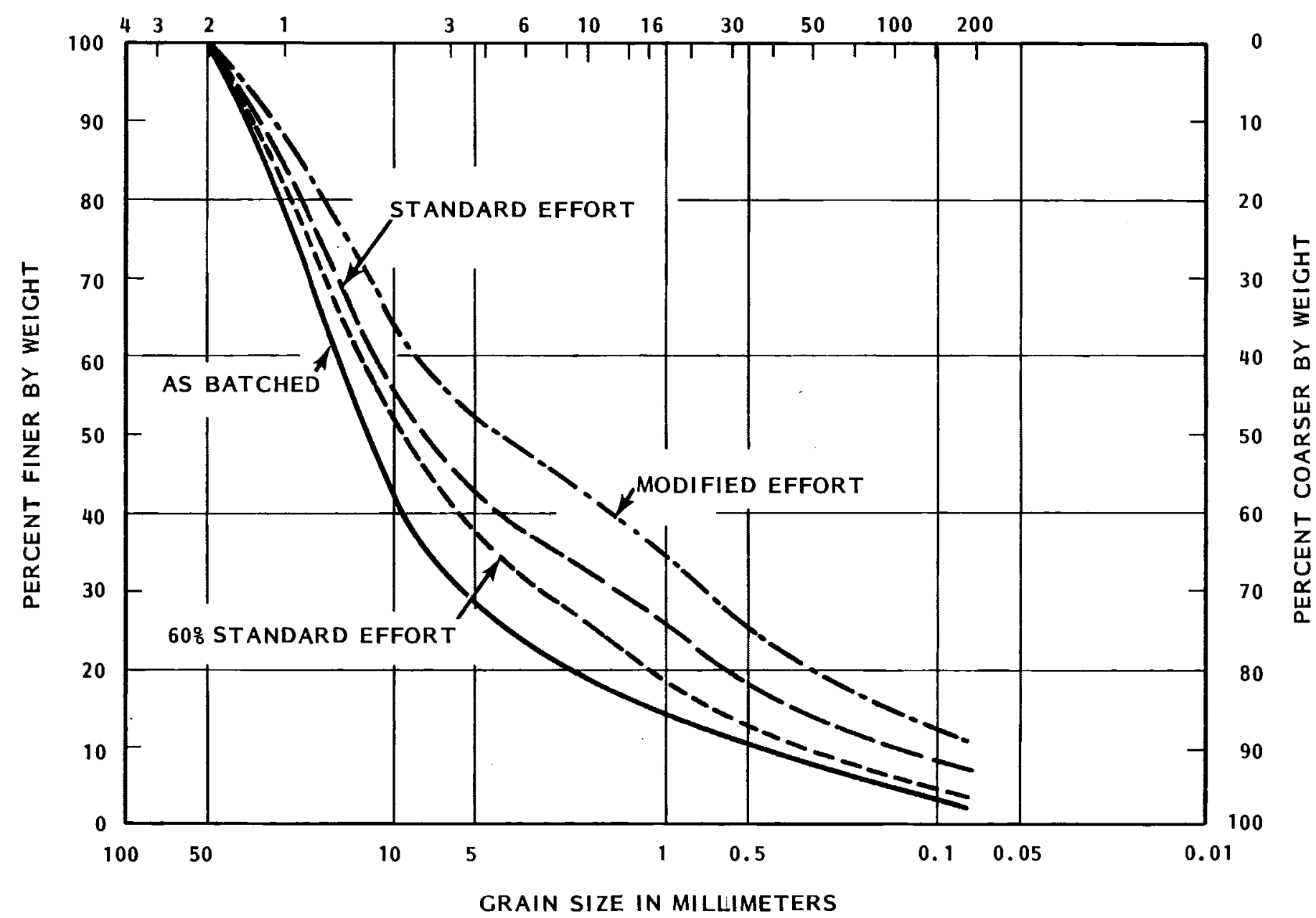

FIGURE 4.3. Effects of Compaction Effort on Gradation for $30.5 \mathrm{~cm}$ (12 in.) dia Compaction Tests on PARAHO Retorted 0il Shale (Townsend and Peterson 1979) 
U.S. STANDARD SIEVE NUMBERS

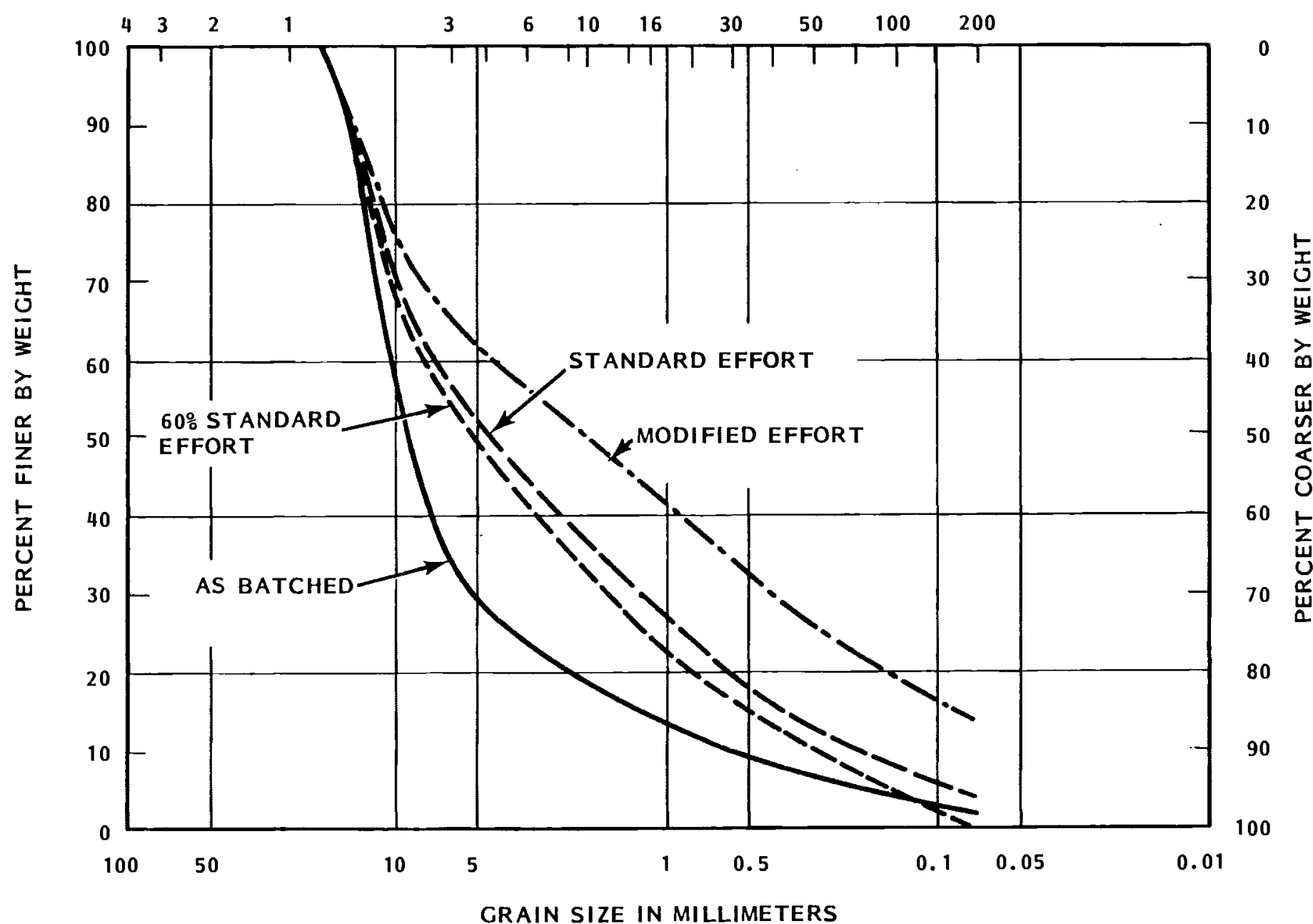

FIGURE 4.4. Effects of Compaction Effort on Gradation for $15 \mathrm{~cm}$ (6 in.) dia Compaction Tests on PARAHO Retored 0 il Shale (Townsend and Peterson 1979) 
TABLE 4.3. Breakage Factors Due to Compaction of PARAHO Material

(Townsend and Peterson 1979)

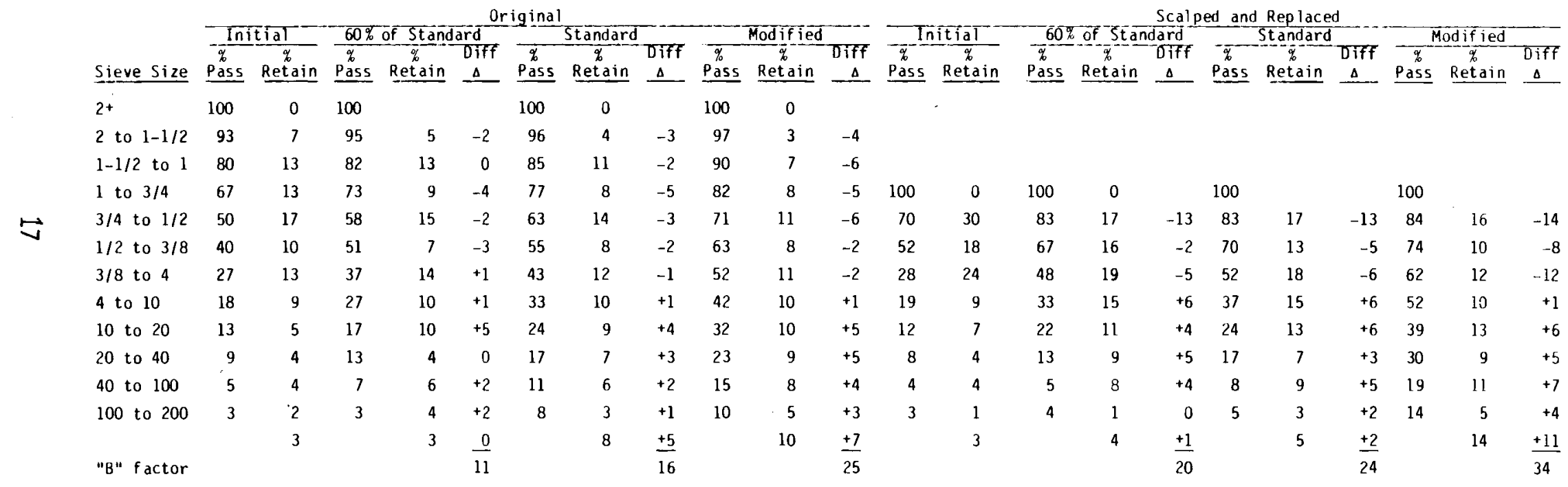




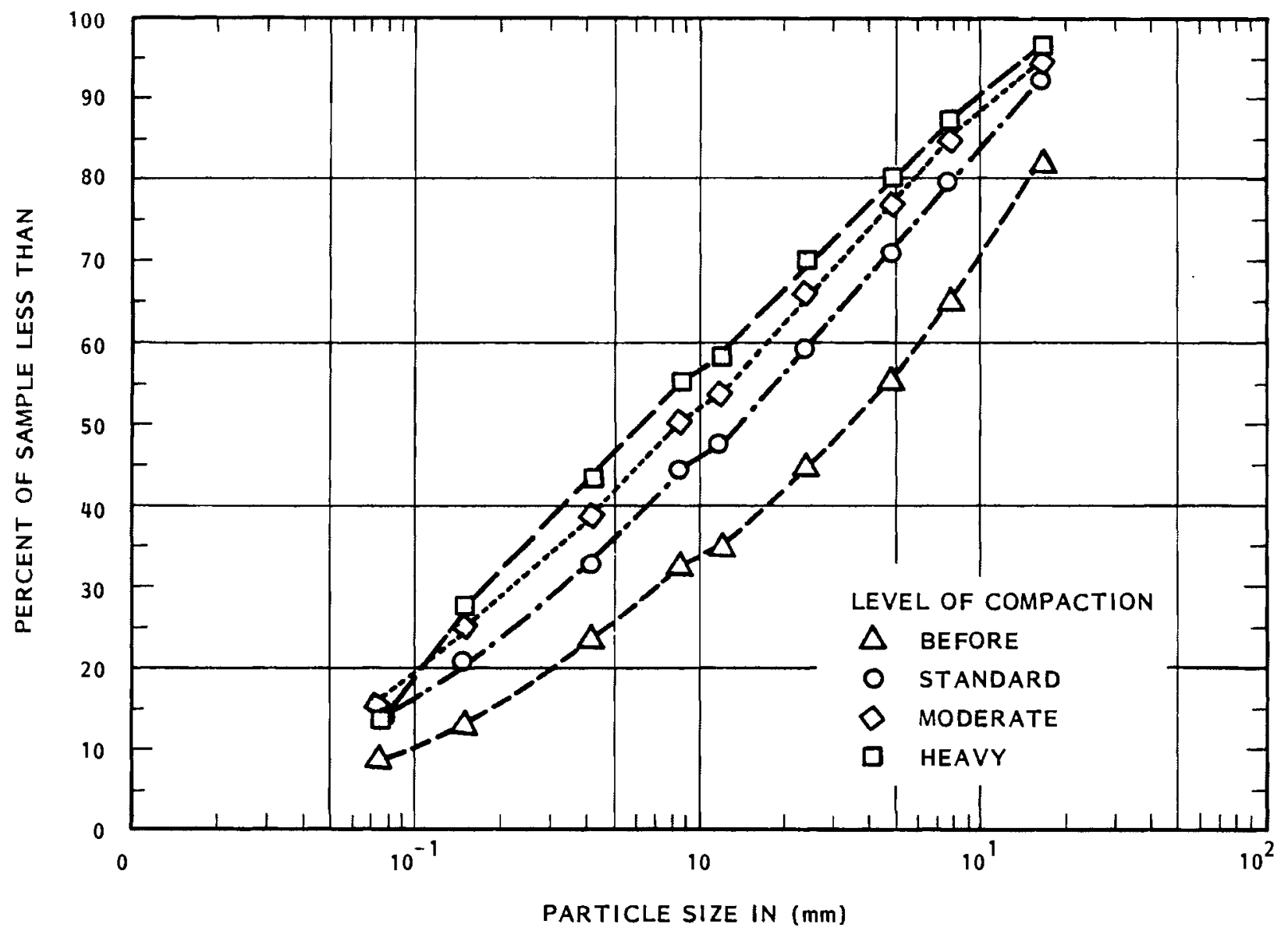

FIgURE 4.5. PARAHO Shale Particle Size Distribution After Compaction

TABLE 4.4. Percent Settlement Versus Applied Load for Retorted PARAHO Shale (Snethen et al. 1978)

\begin{tabular}{|c|c|c|c|c|c|}
\hline \multirow[b]{2}{*}{ Material } & \multicolumn{2}{|c|}{ Applied Load } & \multirow{2}{*}{$\begin{array}{c}\text { Sett lement } \\
\text { percent }\end{array}$} & \multicolumn{2}{|c|}{ Dry Density } \\
\hline & $p s i$ & $\mathrm{KN} / \mathrm{m}^{2}$ & & $p c f$ & $\mathrm{KN} / \mathrm{m}^{3}$ \\
\hline PARAHO & $\begin{array}{r}50 \\
100 \\
200\end{array}$ & $\begin{array}{r}345 \\
689 \\
1379\end{array}$ & $\begin{array}{l}0.7-2.8 \\
0.8-3.4 \\
0.8-4.8\end{array}$ & $\begin{array}{l}95.5-88.0 \\
95.5-98.3 \\
95.5-98.3\end{array}$ & $\begin{array}{l}15.0-13.8 \\
15.0-15.4 \\
15.0-15.4\end{array}$ \\
\hline & $\begin{array}{r}70 \\
145 \\
300 \\
1000\end{array}$ & $\begin{array}{r}483 \\
1000 \\
2068 \\
6895\end{array}$ & $\begin{array}{l}0.4-3.4 \\
0.7-4.8 \\
0.8-5.6 \\
5.3-10.7\end{array}$ & $\begin{array}{l}88.8-102.5 \\
85.0-97.4 \\
85.0-97.4 \\
80.2-96.6\end{array}$ & $\begin{array}{l}13.9-16.1 \\
13.4-15.3 \\
13.4-15.3 \\
12.6-15.2\end{array}$ \\
\hline
\end{tabular}


The total vertical strains in the WES study varied from 4.7 to 10.0 percent when the vertical stress was $5,516 \mathrm{kN} / \mathrm{m}^{2}$ (800 psi) and the maximum dry density around $15.3 \mathrm{kN} / \mathrm{m}^{3}(97.5 \mathrm{pcf})$ for standard compaction energy. WCC obtained settlement values ranging from 2.2 to 11.3 percent with a vertical stress of $6,895 \mathrm{kN} / \mathrm{m}^{2}$ (1000 psi) and a maximum dry density of $14.2 \mathrm{kN} / \mathrm{m}^{3}$ (90.2 pcf). These results agree quite well with each other, as well as the results presented by Snethen et al. (1978).

The compressibility of compacted PARAHO material is comparable to that of dense rockfill or sands. Approximately 28 percent particle breakage during consolidation $c$ an be experienced for standard effort densities consolidated to $5,516 \mathrm{kN} / \mathrm{m}^{2}$ (800 psi) normal stress.

\subsection{STRENGTH}

The stability or load carrying capacity of retorted oil shale is determined by its strength characteristics. Strength has been quantified using several parameters and tests, i.e., compressive strength, modulus values, and triaxial shear strength.

\subsubsection{Unconfined Compression Test}

The self-cementing characteristics of spent shale are well documented (Farris 1979, Holtz 1976, Snethen et al. 1978, Townsend and Peterson 1979) and have been tested by the unconfined compression test. Summarized in Figure 4.6 and Table 4.5 are unconfined compression results for PARAHO material performed by WES. Comparisons between these results and previous test results by WCC are given below.

\section{Unconfined Compressive Strength, psi}

\begin{tabular}{|c|c|c|c|}
\hline \multirow{2}{*}{$\begin{array}{c}\text { Compact ion } \\
\text { Eff ort }\end{array}$} & \multicolumn{2}{|c|}{ WES } & WCC \\
\hline & dd & $28 d$ & $28 \mathrm{dat} 123^{\circ} \mathrm{F}$ \\
\hline $\begin{array}{l}60 \% \text { of Standard } \\
\text { Standard } \\
\text { Modified }\end{array}$ & $\begin{array}{r}5.7 \\
8.2 \\
61.3\end{array}$ & $\begin{array}{r}27.4 \\
66.8 \\
194.8\end{array}$ & $\begin{array}{l}150 \text { to } 175 \\
150 \text { to } 175 \\
175 \text { to } 200\end{array}$ \\
\hline
\end{tabular}




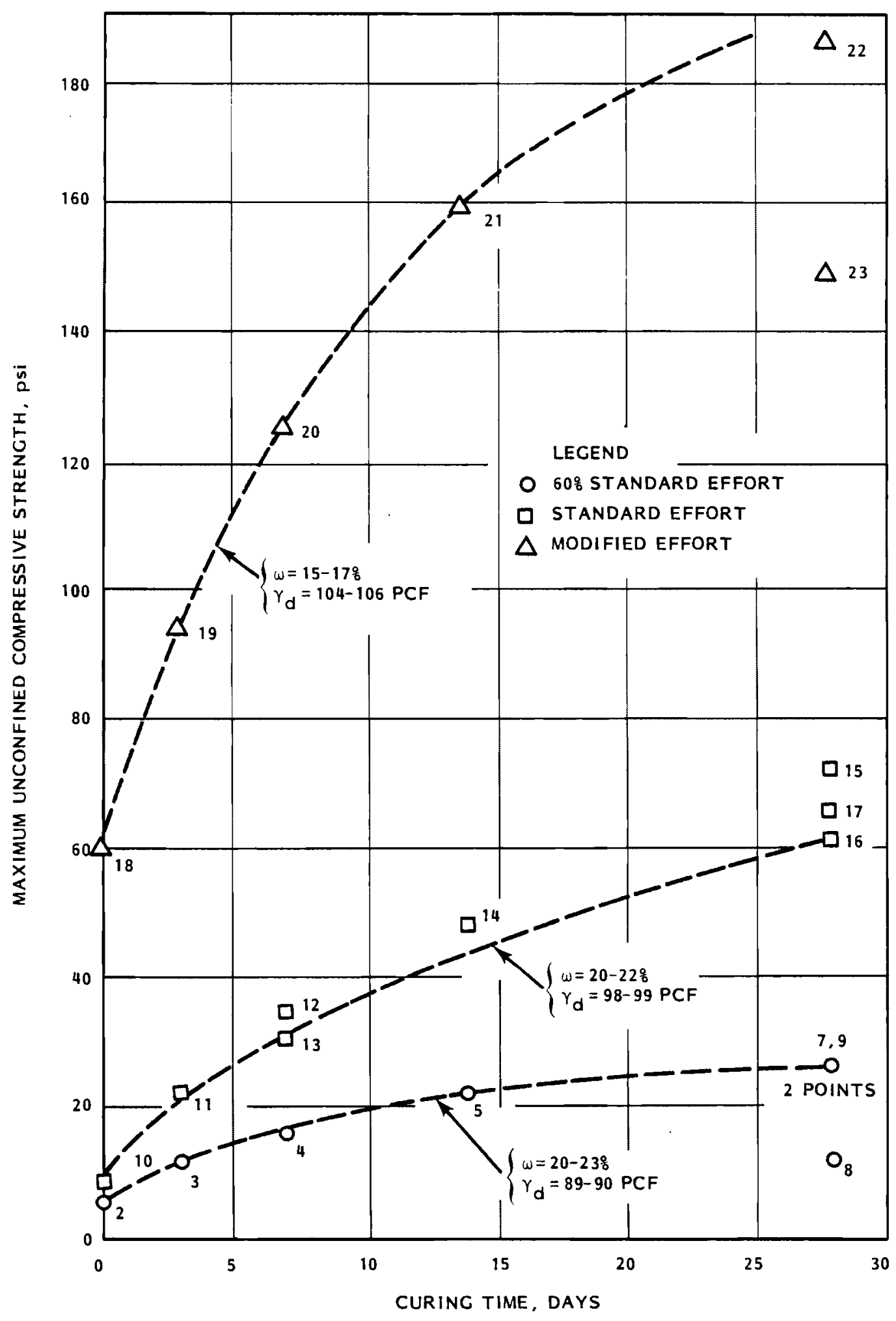

FIGURE 4.6. Effect of Curing Time on the Unconfined Compressive Strength for Compacted PARAHO ( 1 ps $i=6.9 \mathrm{kPA}$ ) (Townsend and Peterson 1979) 
TABLE 4.5. Summary of Unconfined Test Results on PARAHO 0il Shale (Townsend and Peterson 1979)

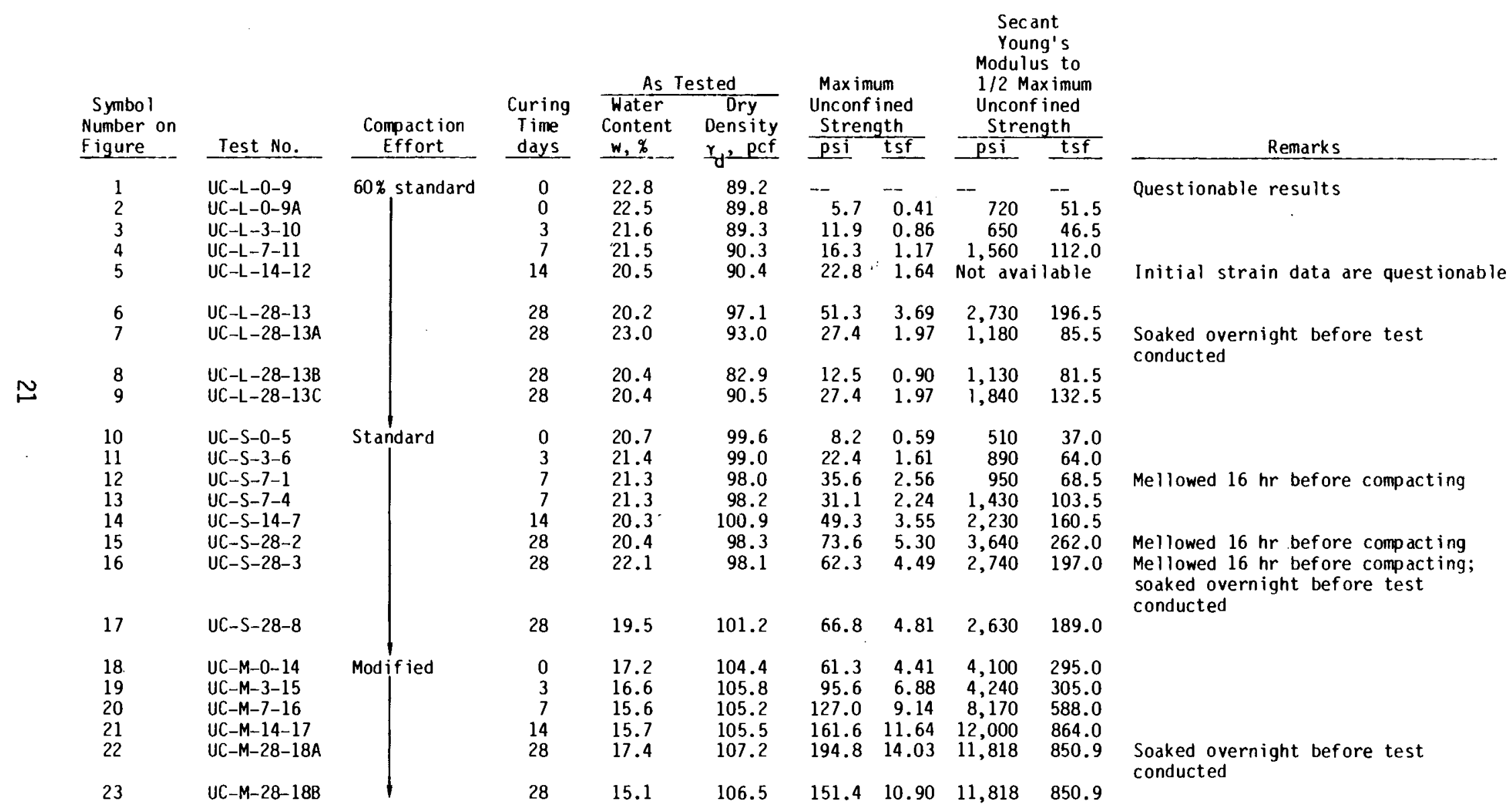


Considering differences in curing temperatures, percent fines and gradation differences, and the amount of time between retorting and compaction (all affecting cementing reactions) the variance between the two studies for the $60 \%$ of standard and standard compaction effort may be explained. The comparisons are fairly close for the modified compaction effort, however.

The time between mixing and compaction, "mellowing time", is an important construction consideration for stabilized soils. The results presented in Table 4.5 shows that mellowing times up to 16 hours had no effect on resulting unconfined compressive strengths. If self-cementing is desired several important design and construction guidelines are evident based upon these considerations (Snethen et al. 1978):

1. PARAHO satisfies recommended criteria for lime stabilized soils, hence, would be judged as a suitable stabilized material.

2. Increased density produces higher strengths.

3. Mellowing times up to 16 hours have little effect on self-cementing of PARAHO. This time should be kept to a minimum, however. Increased compaction effort $c$ an be substituted to obtain greater strengths, if the expense of increased compaction effort is justified.

4. The self-cementing components do not deteriorate significantly due to exposure to air after retorting. To maximize self-cementing, exposure time between retorting and placement should be minimized.

5. Self-cementing characteristics of PARAHO are retained.

6. Cementing reactions under normal curing conditions for PARAHO are slow. Additional strength gains are indicated after 28 days. Heavy equipment should be restricted from tracking compacted areas at least 7 to 14 days following compaction.

An equation to estimate the 3 to 8 fold increase in compressive strength from the cementation has been proposed by Farris (1979) and given below.

$$
C S^{\star}=\frac{A}{1+D e^{-K T}}
$$


where,

$$
\begin{aligned}
C S & =\text { compressive strength, psi } \\
A & =\text { coefficient related to ultimate compressive strength, psi } \\
D & =\text { coefficient related to initial compressive strength, } 1 / p s i \\
K & =\text { coefficient related to rate of cementation, } 1 / \text { days } \\
T & =\text { curing time, days }
\end{aligned}
$$

* Considerable variability in the results was observed; the predictive equation above fits the results to within approximately $345 \mathrm{kN} / \mathrm{m}^{2}$ (50 psi) (Farris 1979).

With an assumed safety factor of 3, a design loading value of $572 \mathrm{kN} / \mathrm{m}^{2}$ (83 psi) can be considered when using PARAHO materials for construction of waste disposal dams and embankments (Farris 1979). Inconsistent quality of the material would require careful considerations of its properties and variability for engineering design use, however.

\subsubsection{Triaxial Compression Test}

Presented in Table 4.6 is a summary of consolidated-drained (S) and undrained $(\bar{R})$ triaxial compression tests on PARAHO material performed by WES. Interpretation of shear strength parameters based on total stresses from $\bar{R}$ test envelopes is influenced by several factors:

1. curved failure envelopes,

2. negative pore pressures, and

3. criteria selecting maximum deviator stress.

Typically the failure envelope is curved, based upon total stresses, thus the angle of internal friction ( $\phi$ ) and cohesion (C) are often only for the higher confining stresses.

WCC provided strength parameters of $\mathrm{C}^{\prime}=1.95 \mathrm{~kg} / \mathrm{cm}^{2}(27.7 \mathrm{psi})$ and $\phi^{\prime}=34.2$ degrees for $S$ triaxial compression tests on $15 \mathrm{~cm}$ ( 6 in.) dia specimens of $4 \mathrm{~cm}$ ( $11 / 2$ in.) maximum particle sized PARAHO material at standard density (Holtz 1976). Where $\phi^{\prime}$ and $C^{\prime}$ are the effective angle of friction and effective cohesion, respectively. These values agree quite well with those observed in the WES investigation. 
TABLE 4.6. Summary of Consolidated-Drained $(S)$ and -Undrained $(\bar{R})$ Triaxial Compression Tests on PARAHO Material (Townsend and Peterson 1979)

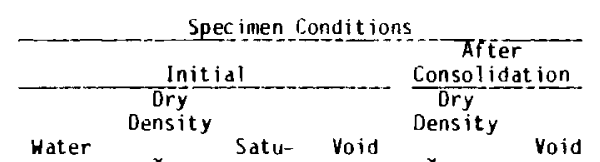

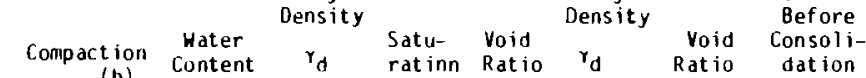

Test no. (a) Effort (b)

S-P-9-L-20-1

S. $P-9-\lfloor-40-1$

S.P. $-9-L-80-1$

S-P - - - L - - 160-1

$\tilde{+}$

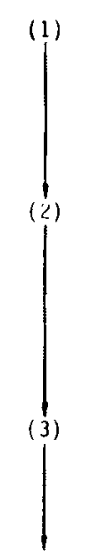

$\begin{array}{rrrrrr}17.0 & 90.1 & 57.8 & 0.738 & 90.9 & 0.724 \\ 18.3 & 89.3 & 62.2 & 0.753 & 91.4 & 0.714 \\ 23.3 & 89.2 & 79.1 & 0.756 & 92.2 & 0.700 \\ 17.8 & 88.7 & 60.6 & 0.765 & 95.4 & 0.643 \\ & & & & & \\ 18.7 & 95.1 & 72.8 & 0.654 & 95.9 & 0.640 \\ 17.3 & 95.1 & 67.2 & 0.654 & 96.6 & 0.629 \\ 17.5 & 95.2 & 68.2 & 0.652 & 98.1 & 0.604 \\ 18.1 & 96.5 & 70.6 & 0.629 & 98.0 & 0.618 \\ 18.6 & 94.6 & 72.7 & 0.662 & 97.0 & 0.622 \\ & & & & & \\ 13.1 & 98.7 & 51.5 & 0.606 & 99.5 & 0.594 \\ 12.9 & 100.3 & 50.6 & 0.581 & 101.2 & 0.567 \\ 13.0 & 100.3 & 51.2 & 0.581 & 101.8 & 0.558 \\ 12.8 & 98.5 & 50.4 & 0.601 & 101.7 & 0.559\end{array}$

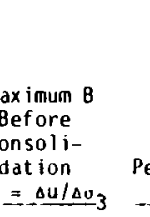

At Maximum Effective Stress Ratio, $\vec{Z}_{\text {Effective }} I_{-}$

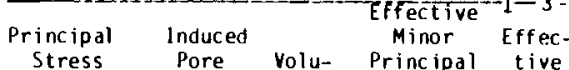

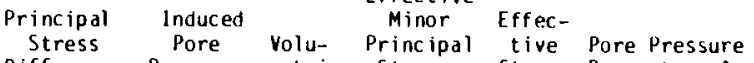

Strain Stress Stress Parameter, A

Permeability $v_{1}-a_{2} \quad u-u_{0} \quad \begin{aligned} & \text { Strain } \\ & \Delta V / V\end{aligned} \bar{\sigma}_{3}, \quad$ Ratio $A=u_{0}-u_{0} \quad$ Strain

$0.97 \quad 1.5 \times 10^{-2(c)}$

$\begin{array}{lll}0.97 & 1.5 \times 10^{-2(c)} \quad 6.23 \\ 0.97 & 1.0 \times 10^{-2(c)}\end{array}$ $\mathrm{kg} / \mathrm{cm}^{2} \quad \Delta \quad$ q

$\mathrm{kg} / \mathrm{cm}^{2}$

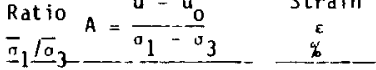

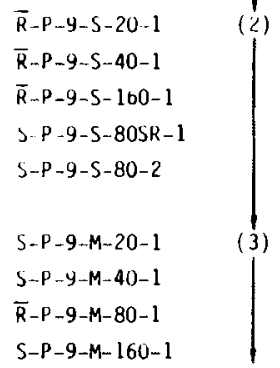

12.898 .5

$0.97 \quad 5.8 \times$

$0.96 \quad 2.7 \times 10^{-3}$

14.29

$1.66 \quad 4.75 \quad \mathrm{~N} / \mathrm{A}$

15.02

$0.97 \quad 4.6 \times 10^{-3}$

$0.98 \quad 1.9 \times 10^{-3}$

$0.96 \quad 5.2 \times 10^{-4}$

$0.97 \quad 6.8 \times 10^{-4}$

6.13

10.61

18.79

$\mathrm{N} / \mathrm{A} \quad 4.81$

$3.04 \quad 3.94$

$M / A$

13.2

27.54

$\mathrm{N} / \mathrm{A} \quad 7.6$

11.35

3.43

N/A

15.2

$0.97 \quad 6.2 \times 10^{-4} \quad 14.81$

$0.68 \quad \mathrm{~N} / \mathrm{A}$

$\begin{array}{ll}1.59 & N / A \\ 8.65 & N / A\end{array}$

$0.80 \quad 6.02$

\subsection{7}

$\begin{array}{ll}2.73 & 4.89\end{array}$

0.81

N/A

1.5

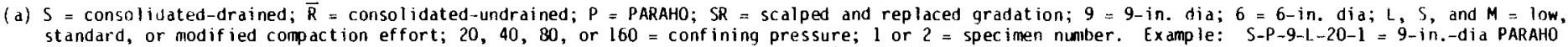

(b) (1) indicates $60 \%$ of $5 t$ andard $\left(G_{s}=2.51\right) ;(2)$ standard $\left(G_{s}=2.52\right) ;$ and $(3)$ modified $\left(G_{s}=2.54\right)$.

(c) Permeability dat a may be questionable. 
Figures 4.7 and 4.8 present the effective stress paths, Mohr's circles based on maximum effective principle stress ratio, and the total and effective stress envelopes for PARAHO materials. The following tabulation summarizes and compares the total and effective stress parameters (Townsend and Peterson 1979).

\begin{tabular}{|c|c|c|c|c|c|}
\hline \multirow{2}{*}{$\begin{array}{r}\text { Material and } \\
\text { Compaction Effort } \\
\end{array}$} & \multirow{2}{*}{$\begin{array}{l}\text { Maximum } \\
\text { Particle } \\
\text { Size, in. }\end{array}$} & \multicolumn{2}{|c|}{ Total Stress } & \multicolumn{2}{|c|}{ Effective Stress } \\
\hline & & $\phi$, deg & $\mathrm{c}, \mathrm{kg} / \mathrm{cm}^{2}$ & $\phi^{\prime}$, deg & $\mathrm{c}^{\prime}, \mathrm{kg} / \mathrm{cm}^{2}$ \\
\hline $\begin{array}{l}\text { PARAHO } \\
\text { S-in.-diam, } 60 \% \text { of Standard } \\
\text { Standard } \\
\text { Modif ied }\end{array}$ & $\begin{array}{l}1-1 / 2 \\
1-1 / 2 \\
1-1 / 2\end{array}$ & $\begin{array}{l}14.5 \\
31.0(a)\end{array}$ & $\begin{array}{l}1.3 \\
0\end{array}$ & $\begin{array}{l}33.0 \\
32.7 \\
32.3\end{array}$ & $\begin{array}{l}0.9 \\
0.8 \\
1.9\end{array}$ \\
\hline $\begin{array}{l}\text { Mode led PARAHO } \\
\text { 9-in.-diam, Standard (a) } \\
\text { 6-in.-diam, Standard }\end{array}$ & $\begin{array}{l}3 / 4 \\
3 / 4\end{array}$ & 17.1 & 1.7 & $\begin{array}{l}38.0 \\
37.9\end{array}$ & $\begin{array}{l}0 \\
1.1\end{array}$ \\
\hline$\frac{\text { PARAHO Fines }}{1.4-i n .-d i a m}$, Standard & & 23.2 & 1.7 & 33.6 & 2.3 \\
\hline
\end{tabular}

For these confining stresses typically well graded compacted gravels have effective angles of internal friction ranging from 40 to 45 degrees. It may be concluded that PARAHO is slightly weaker than similarly graded gravels even though it possess adequate strength. Further, increased compaction effort does not noticeably improve PARAHO's shear strength parameters.

\subsection{PERMEABILITY}

Figure 4.9 presents results of permeability measurements, preceding shear of triaxial compression tests, on specimens of PARAHO materials compacted to densities comparable to 60 percent of standard, standard, and modified compaction efforts performed by WES. Also shown are permeability values based upon consolidation tests by WES. Both sets of data are consistent and show decreasing permeabilities with decreasing void ratios. For 60 percent of standard effort densities the permeabilities for PARAHO decreased from $10^{-3} \mathrm{~cm} / \mathrm{s}$ to $10^{-4} \mathrm{~cm} / \mathrm{s}$ for modified effort densities. The permeabilities determined from consolidation tests reflect lower values due to lower void ratios achieved from higher consolidation stresses. 


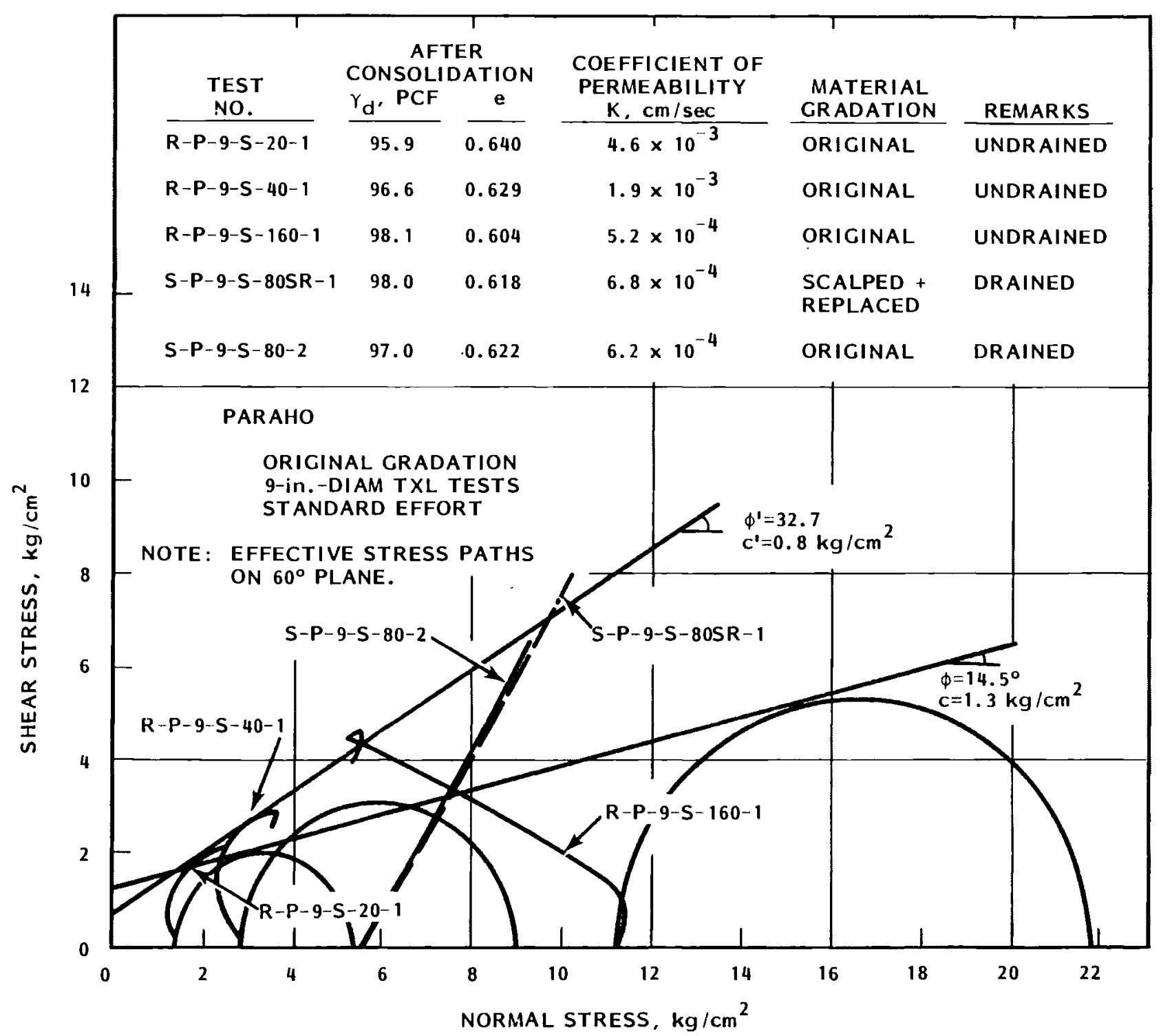

FIGURE 4.7. Total and Effective Stress Envelopes for PARAHO Compacted to Standard Effort Density (Townsend and Peterson 1979) 


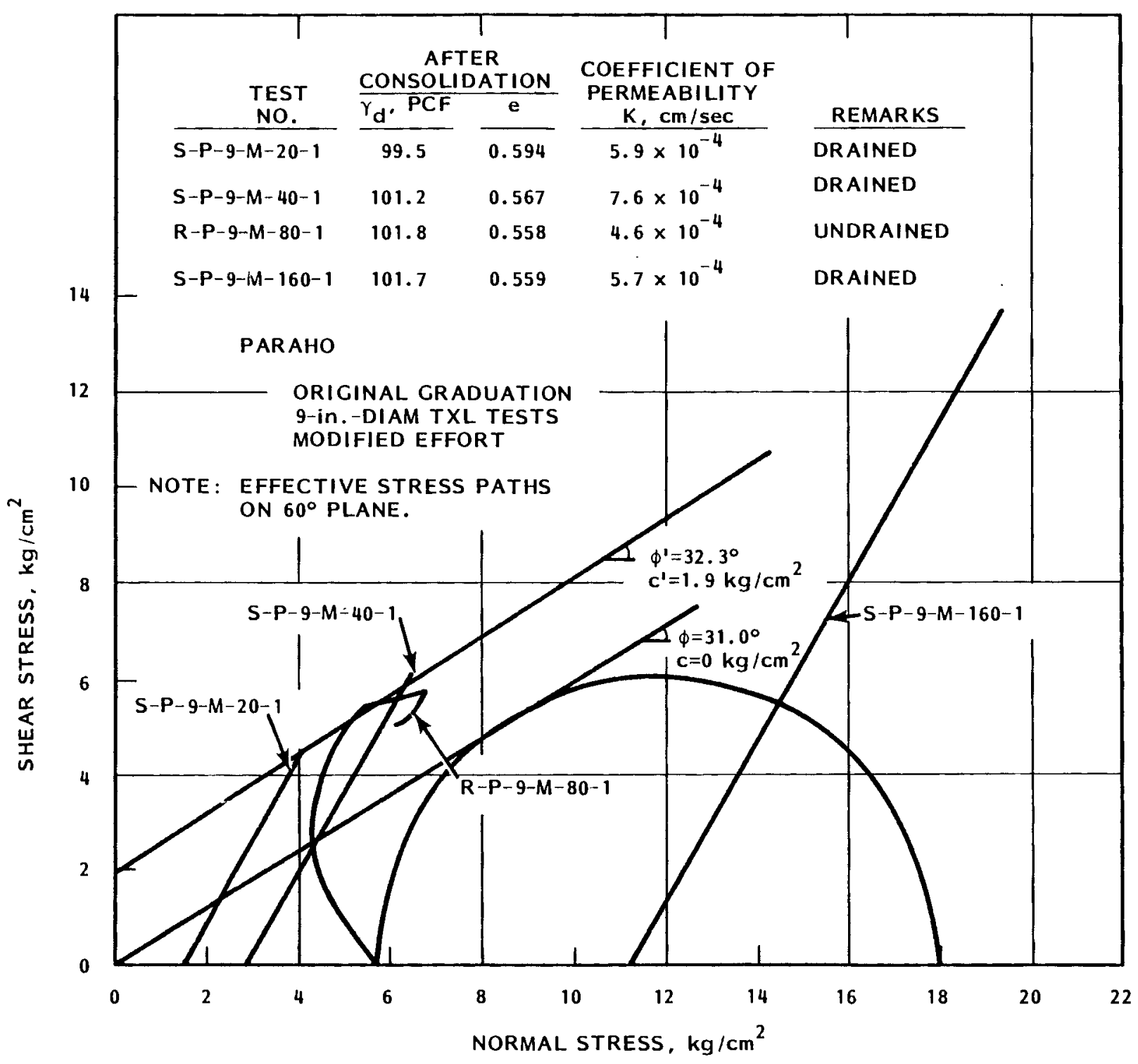

FIGURE 4.8. Effective Stress Envelope for PARAHO Compacted to Modified Effort Density (Townsend and Peterson 1979) 
Permeability values determined by $W C C$ on $20 \mathrm{~cm}$ ( 8 in.) dia specimens of $4 \mathrm{~cm}$ (1 $1 / 2$ in.) PARAHO material are also presented in Figure 4.9 for comparison. This comparison shows considerably lower permeabilities for comparable void ratios due to the greater amount of fines for WCC material than the WES material.

Using two different sampling apparatuses, permeability data were collected for full size PARAHO material at PNL and the results shown in Table 4.7. A $18 \mathrm{~cm}$ by $18 \mathrm{~cm}$ ( $7 \mathrm{in}$. by $7 \mathrm{in.}$ ) square column, $2 \mathrm{~m}(6 \mathrm{ft})$ high was used along with a $15 \mathrm{~cm}$ (6 in.) dia cylindrical cell, $15 \mathrm{~cm}$ (6 in.) high for comparison. Both apparatuses were packed with a low density and a high density pack. The permeability range between the two apparatuses is shown in Figure 4.10 for each respective packing.

The results of Townsend and Peterson (1979) are also shown in Figure 4.10 for comparison. The variance between results are due to differences in packing conditions (density) and the amount of fines present.

\subsection{SOUNDNESS}

The soundness of an aggregate material is a measure of its ability to resist degradation from an applied force. Soundness is quantified using the Los Angeles Abrasion test (LAA). Shown below is a summary of Los Angeles Abrasion tests on PARAHO shale. With LAA values of $79.7,80.1$, and 66.7 percent for the various gradations the PARAHO retorted shale is quite susceptible to abrasion. All of the values exceed the maximum acceptable value of 40 percent for base coarse materials. 


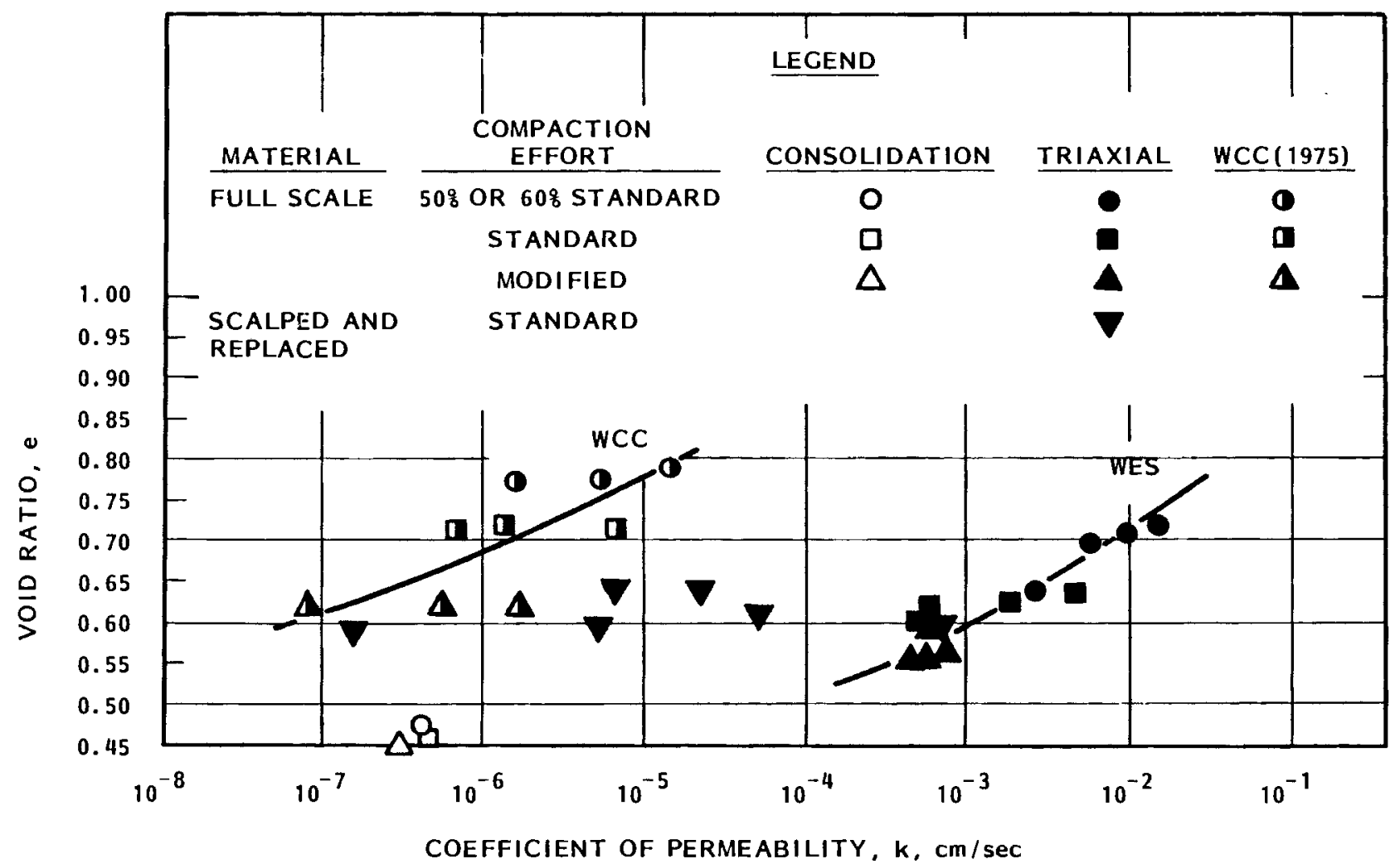

FIGURE 4.9. Permeability-Void Ratio Relationships for Compacted PARAHO Retorted 0il Shale (Townsend and Peterson 1979) 


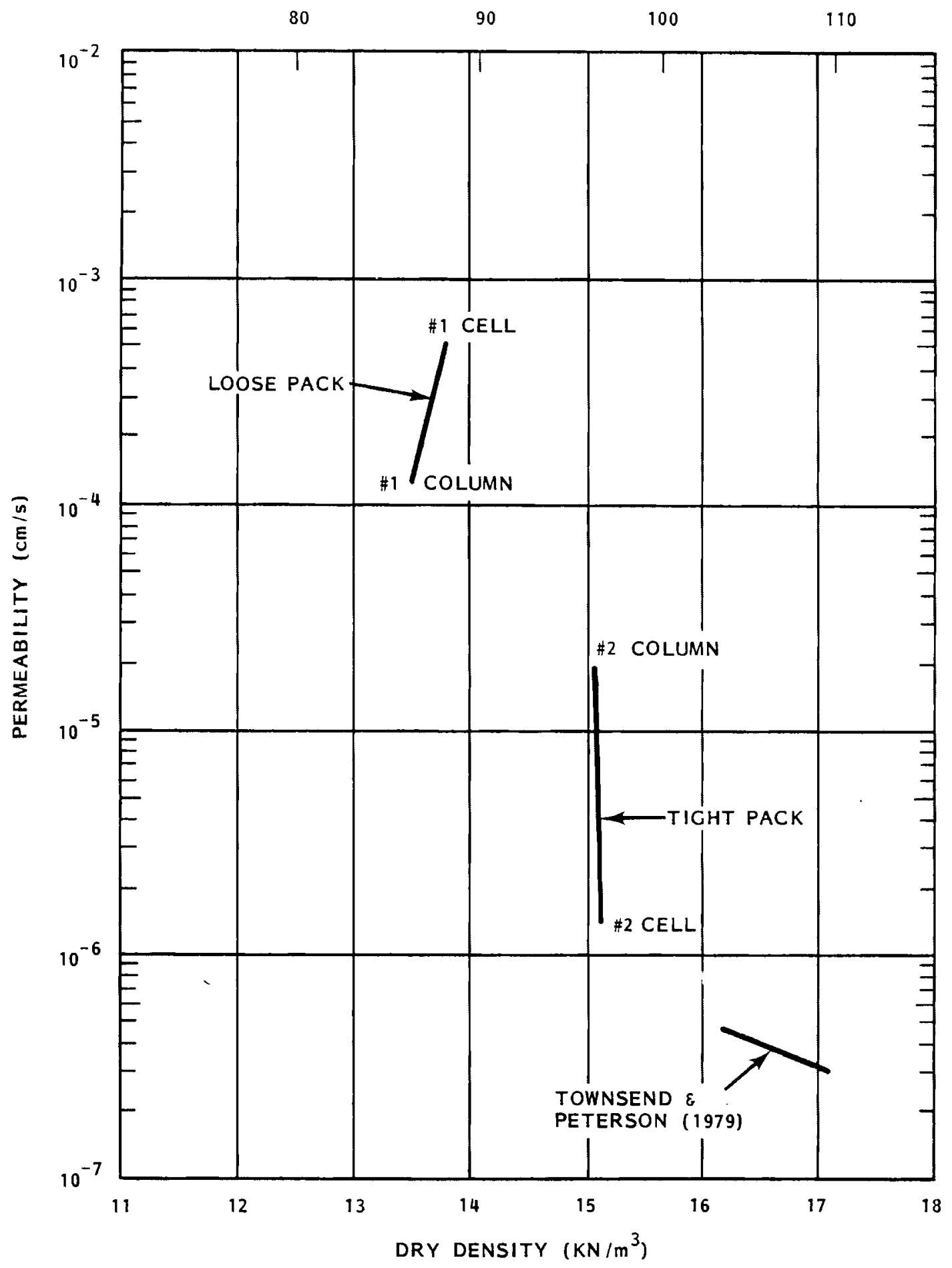

FIGURE 4.10. Permeability Values for Full Size PARAHO Material 
TABLE 4.7. Permeability of PARAHO Shale at Different Dry Bulk Densities

\begin{tabular}{|c|c|c|}
\hline Samp le & $\begin{array}{c}\text { Dry Bulk Density } \\
\frac{(\mathrm{g} / \mathrm{cm} 3)}{}\end{array}$ & $\begin{array}{l}\text { Permeability } \\
\quad(\mathrm{cm} / \mathrm{s})\end{array}$ \\
\hline Column No. 1 (Loose Pack) & 1.32 & $1.2 \times 10^{-4}$ \\
\hline Column No. 2 (Tight Pack) & 1.53 & $2.0 \times 10^{-5}$ \\
\hline Cell No. 1 (Loose Pack) & 1.41 & $5.0 \times 10^{-4}$ \\
\hline Cell No. 2 (Tight Pack) & 1.54 & $1.4 \times 10^{-6}$ \\
\hline
\end{tabular}

TABLE 4.8. Summary of Los Angeles Abrasion Test Results on PARAHO Shale (Townsend and Peterson 1979)

\begin{tabular}{|c|c|c|c|c|}
\hline Material & $\begin{array}{c}\text { ASTM } \\
\text { Designation }\end{array}$ & Grading & Sieve Size, in. & $\begin{array}{c}\text { Percentage } \\
\text { Wear } \\
\end{array}$ \\
\hline PARAHO & C131-76 & A & $\begin{array}{l}-1-1 / 2 \text { to }+1 \\
-1 \text { to }+3 / 4 \\
-3 / 4 \text { to }+1 / 2 \\
-1 / 2 \text { to }+3 / 8\end{array}$ & 79.7 \\
\hline PARAHO & C131-76 & c & $\begin{array}{l}-3 / 8 \text { to }+ \text { No. } 3 \\
- \text { No. } 3 \text { to }+ \text { No. } 4\end{array}$ & 80.1 \\
\hline PARAHO & C535-69 & 2 & $\begin{array}{l}-2 \text { to }+1-1 / 2 \\
-1-1 / 2 \text { to }+1\end{array}$ & 66.7 \\
\hline
\end{tabular}



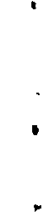


\subsection{OTHER PROPERTIES}

Properties not specifically covered under physical or engineering properties will be covered below.

\subsection{DROP HEIGHT TESTS}

To determine densities achieved when processed oil shale is dropped from various conveyor heights, tests were conducted by WES and the results presented in Table 5.1 and Figure 5.1. Major increase in density occurs within the initial $1.5 \mathrm{~m}(5 \mathrm{ft})$ of drop for PARAHO, where a relative density of 67 percent was achieved. Only a small amount of densification (79 percent) was achieved by increasing the drop height to $5.0 \mathrm{~m}(16.5 \mathrm{ft})$.

TABLE 5.1: Summary of Drop Height Tests on PARAHO Shale (Townsend and Peterson 1979)

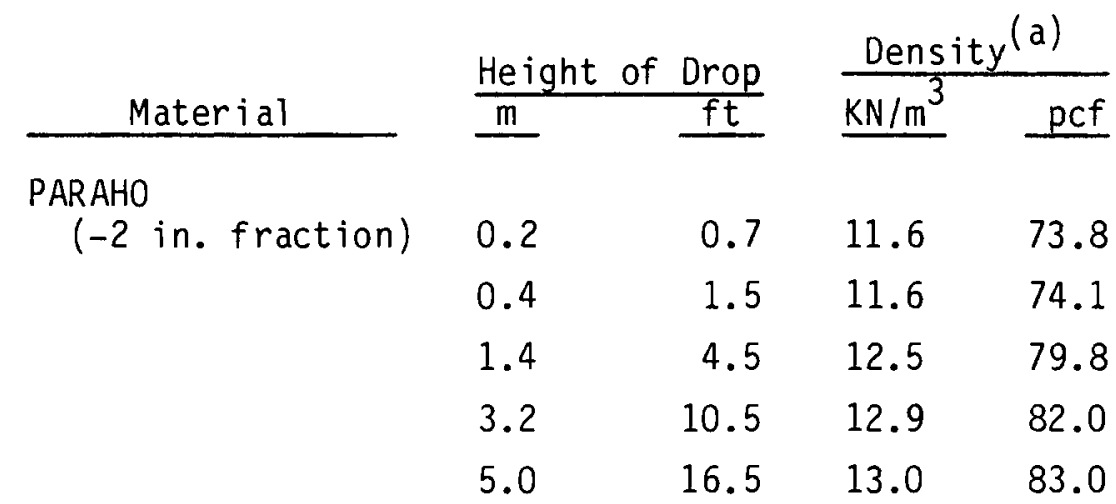

(a) Air dry material (the water content of the PARAHO fractions are less than 1 wt percent)

\subsection{WATER RETENTION CHARACTERISTICS}

Water retention characteristics for PARAHO shale were measured by PNL over a range from saturation to air dry conditions. Water retention data from 20 to $100 \mathrm{~cm}$ ( 8 to $39 \mathrm{in.)}$ were collected by direct gravimetric sampling of $1.8 \mathrm{~m}$ $(6 \mathrm{ft}$ ) permeability columns (Table 5.2) and a pressure plate extractor method 


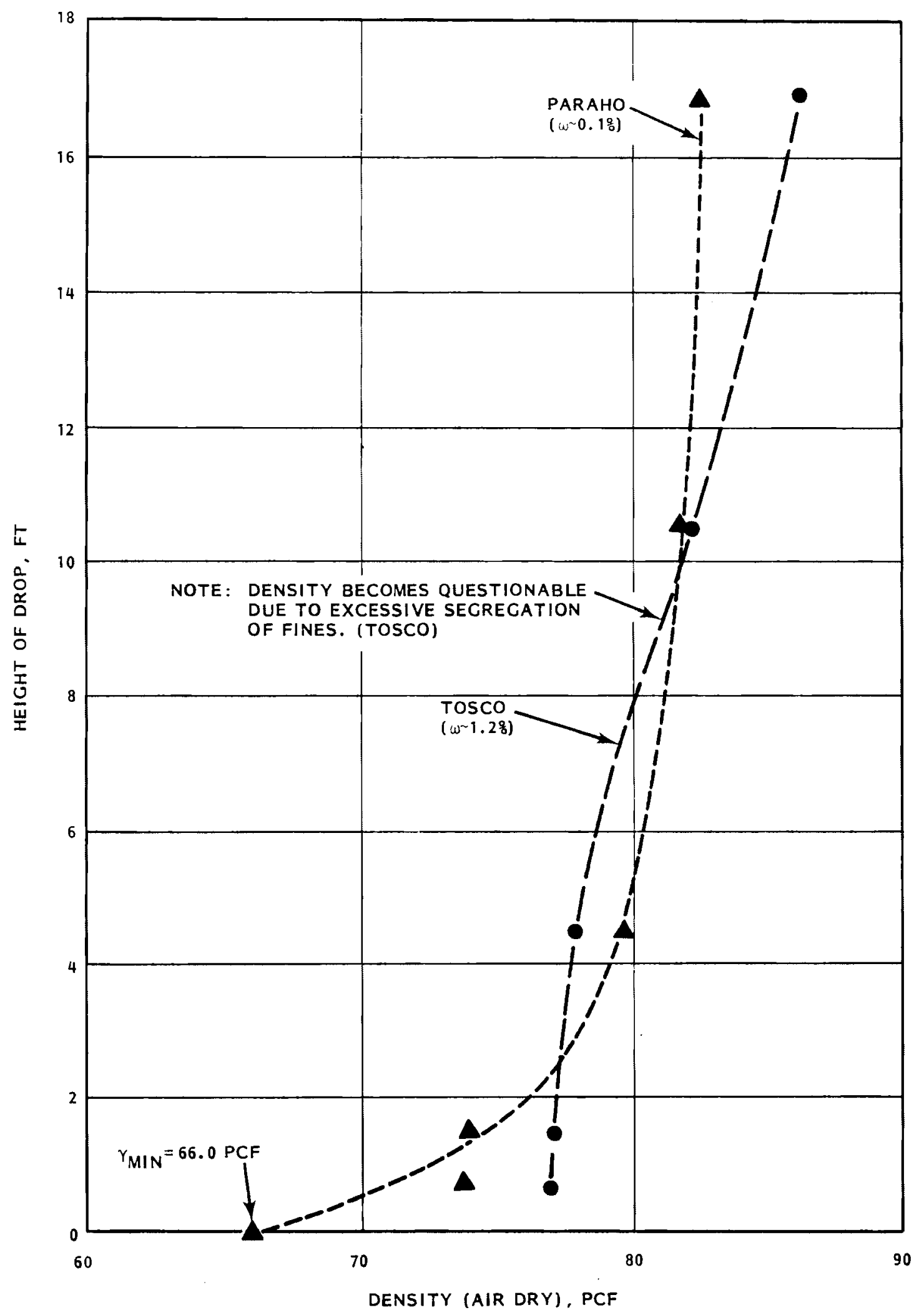

FIGURE 5.1. Effect of Drop Height on Dry Density for PARAHO and TOSCO Retorted 0 il Shales (Townsend and Peterson 1979) 
TABLE 5.2. Water Retention Characteristics by Large Column

\begin{tabular}{|c|c|c|c|}
\hline \multicolumn{2}{|c|}{ Loose Pack } & \multicolumn{2}{|c|}{ Tight Pack } \\
\hline $\begin{array}{l}\text { Head } \\
(\mathrm{cm})\end{array}$ & $\begin{array}{l}\text { Volumetric } \\
\text { Water Content } \\
\left(\mathrm{cm}^{3} / \mathrm{cm}^{3}\right) \\
\end{array}$ & $\begin{array}{l}\text { Head } \\
(\mathrm{cm})\end{array}$ & $\begin{array}{c}\text { Volumetric } \\
\text { Water Content } \\
\left(\mathrm{cm}^{3} / \mathrm{cm}^{3}\right) \\
\end{array}$ \\
\hline 8.0 & 0.412 & 15.5 & 0.381 \\
\hline 28.0 & 0.401 & 35.5 & 0.394 \\
\hline 48.0 & 0.362 & 55.5 & 0.359 \\
\hline 68.0 & 0.344 & 75.5 & 0.365 \\
\hline 88.0 & 0.348 & 95.5 & 0.349 \\
\hline 108.0 & 0.340 & 115.5 & 0.362 \\
\hline 128.0 & 0.337 & 135.5 & 0.342 \\
\hline 148.0 & 0.322 & 155.5 & 0.320 \\
\hline Dry Bulk Density & $y \quad 12.9$ & & \\
\hline $\begin{array}{l}\text { Porosity (a) } \\
\qquad\left(\mathrm{cm}^{3} / \mathrm{cm}^{3}\right)\end{array}$ & 0.511 & & \\
\hline Void Ratio & 1.045 & & \\
\hline
\end{tabular}

(a) Assumes a particle density of $2.70 \mathrm{~g} / \mathrm{cm}^{3}$

used for collecting water retention over the range of 100 to $3,000 \mathrm{~cm}(3.25$ to $98.4 \mathrm{ft}$ ) (Table 5.3). Summarized in Figures 5.2 and 5.3 are water retention characteristics for PARAHO shale loose and tight packed, respectively.

Water retention characteristics values determined by Bloomsburg and Wells (1978) on PARAHO material packed at densities of $12.6 \mathrm{kN} / \mathrm{m}^{3}(80.0 \mathrm{pcf})$ and $15.0 \mathrm{kN} / \mathrm{m}^{3}$ (95.0 pcf) are also shown in Figures 5.2 and 5.3 , respectively, for comparison. This comparison shows considerable variance between the two studies, the result of the PARAHO material used during testing. Bloomsburg and Wells (1978) tested samples dry packed with retorted oil shale sieved to $2 \mathrm{~mm}$ and finer, where PNL used "as received" full scale material.

\subsection{FIELD CAPACITY}

To determine the "field capacity" of retorted oil shale, estimates were made by PNL using the technique of Kemper and Walker (1978). Field capacity 
measurements were determined to be $13.83 \%$ (dry wt) for the loose pack [dry bulk density of $11.8 \mathrm{kN} / \mathrm{m}^{3}$ (75 pcf)] and $12.71 \%$ (dry wt) for the tight pack [dry bulk density of $\left.16.1 \mathrm{kN} / \mathrm{m}^{3}(102.5 \mathrm{pcf})\right]$. Based on these measurements, little seepage should occur even in relatively deep piles when conditioned at moisture contents less than 13 or 14\% (dry wt), for these compacted PARAHO materials. At a semi-arid disposal site, where annual deep infiltration is expected to be small or negligible, dry PARAHO treated shale could be moisturized with waste water to at least 0.1 MT (metric ton) retort water per MT of shale without significant drainage from 30 to $50 \mathrm{~m}$ thick piles (Bond et al. 1982). However, moisturization of the pile to optimum water contents [15 to $22 \%$ (dry wt)] will result in drainage. This kind of information will assist in properly engineering the pile for optimum stability as well as minimizing environmental degradation which may result from contaminant seepage from large spent shale piles.

TABLE 5.3. Water Retention Characteristics by Pressure Plate Extractor

\begin{tabular}{|c|c|c|c|}
\hline \multicolumn{2}{|c|}{ Loose Pack } & \multicolumn{2}{|c|}{ Tight Pack } \\
\hline $\begin{array}{l}\text { Head } \\
(\mathrm{cm})\end{array}$ & $\begin{array}{c}\text { Volumetric } \\
\text { Water Content } \\
\left(\mathrm{cm}^{3} / \mathrm{cm}^{3}\right) \\
\end{array}$ & $\begin{array}{l}\text { Head } \\
(\mathrm{cm})\end{array}$ & $\begin{array}{c}\text { Volumetric } \\
\text { Water Content } \\
\left(\mathrm{cm}^{3} / \mathrm{cm}^{3}\right) \\
\end{array}$ \\
\hline 100 & 0.383 & 100 & 0.374 \\
\hline 300 & 0.286 & 300 & 0.364 \\
\hline 1,000 & 0.224 & 1,000 & 0.306 \\
\hline 3,000 & 0.156 & 3,000 & 0.233 \\
\hline $\begin{array}{l}\text { Dry Bulk Density } \\
\left(\mathrm{KN} / \mathrm{m}^{3}\right)\end{array}$ & y 12.2 & & \\
\hline $\begin{array}{l}\text { Porosity (a) } \\
\quad\left(\mathrm{cm}^{3} / \mathrm{cm}^{3}\right)\end{array}$ & 0.537 & & \\
\hline Void Ratio & 1.160 & & 550 \\
\hline
\end{tabular}

(a) Assumes a particle density of $2.70 \mathrm{~g} / \mathrm{cm}^{3}$ 


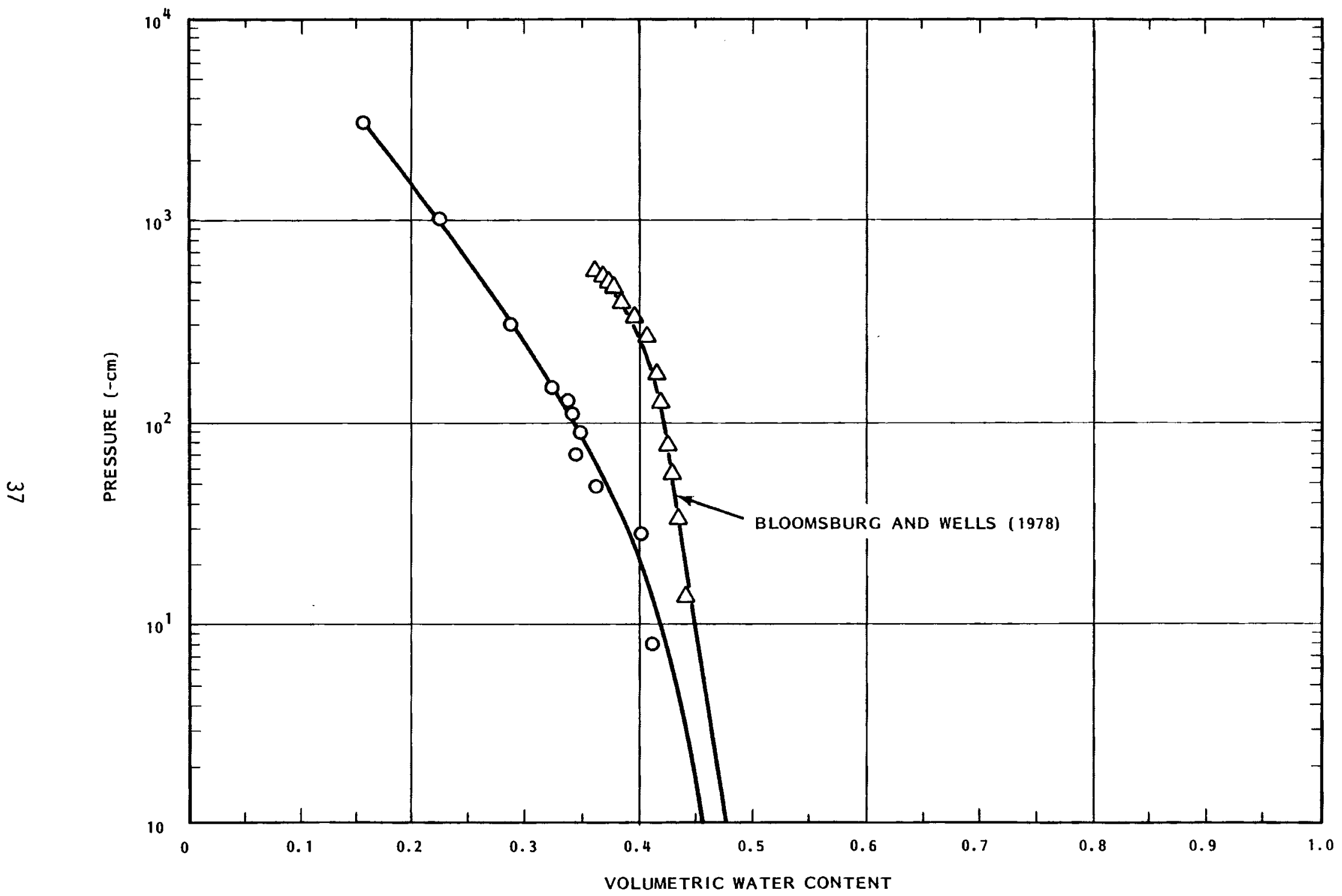

FIGURE 5.2. Water Retention PARAHO Shale "Loose Pack" 


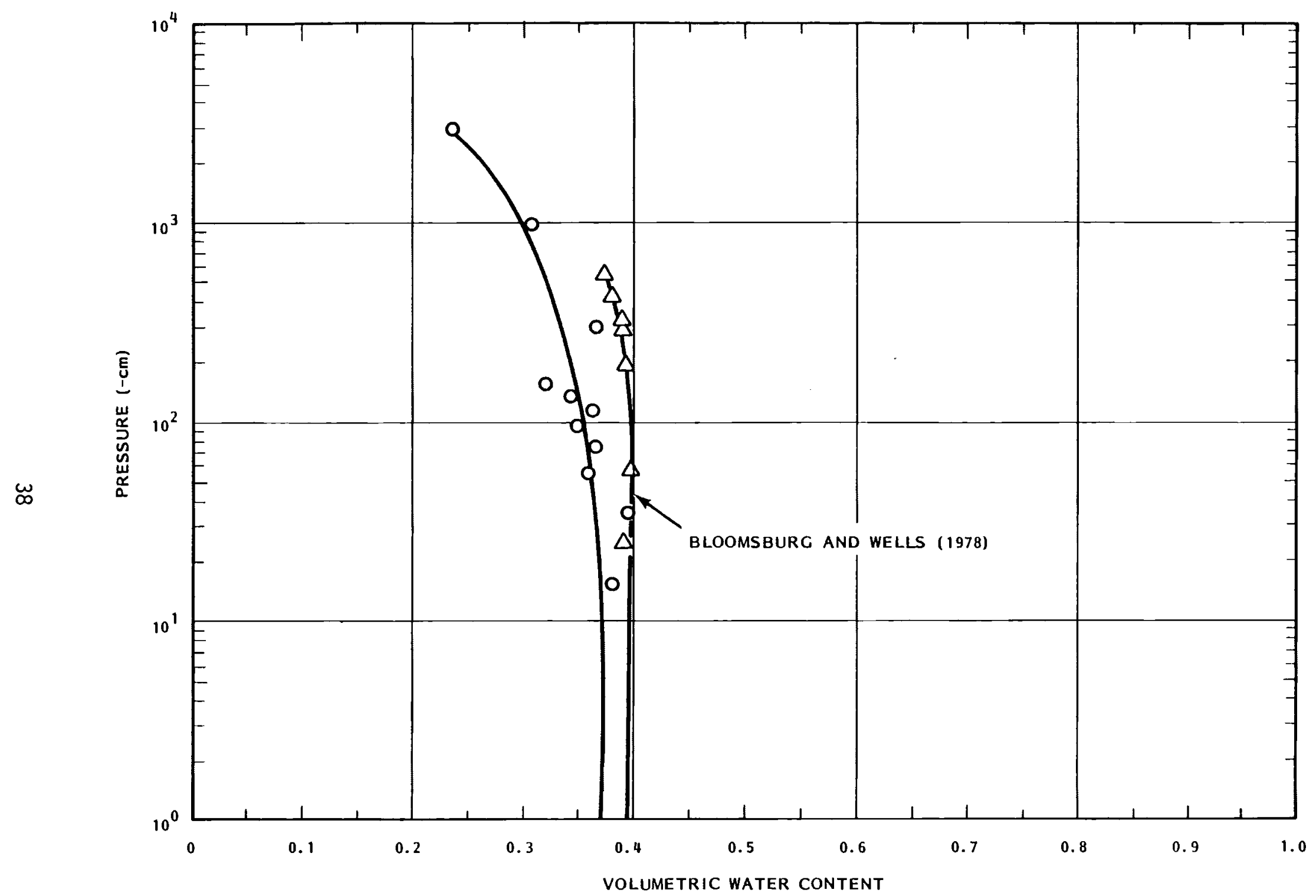

FIGURE 5.3. Water Retention PARAHO Shale "Tight Pack" 


\section{REFERENCES}

B loomsburg, G. L:, and R. D. Wells. 1978. "Seepage Through Partially Saturated Shale Wastes," Final Report to U.S. Bureau of Mines Under Contract $\mathrm{H} 0252065$, prepared by Agricultural Engineering Department, University of Idaho, Moscow, Idaho.

Bond, F. W., M. D. Freshley and G. W. Gee. 1982. Unsaturated Flow Modeling of a Retorted 0 il Shale Pile. PNL-4284. Pacific Northwest Laboratory, Richland, Washington.

Farris, C. B. 1979. "Natural Cementation of Retorted 0il Shale," Final Report to U.S. Bureau of Mines under Contract J0285001, prepared by Colorado School of Mines Research Institute, Golden, Colorado.

Holtz, W. G. 1976. "Research and Development Program on the Disposal of Retorted Oil Shale--PARAHO 0 il Shale Project," First report to the U.S. Bureau of Mines under Contract J025504, prepared by Woodward-Clyde Consultants, Denver, Colorado.

Kemper, W. D. and W. R. Walker. 1978. "Trans-Seasonal Storage of Solar Energy, CSU Report C0014546-3, Ft. Collins, Colorado.

Klute, A. 1965. "Laboratory Measurements of Hydraulic Conductivity of Saturated Soil," In Methods of Soil Analysis, Part I, ed. C. A. Black, American Society of Agronomy, Inc., Madison Wisconsin, p. 210-222.

Snethen, D. R., W. J. Farrell, and F. C. Townsend. 1978. "A Review of the Physical and Engineering Properties of Raw and Retorted $0 i 1$ Shales from the Green River Formation," Miscellaneous Paper S-78-3, U.S. Army Engineers Waterways Experiment Station, CE, Vicksburg, Mississippi.

Townsend, F. C., and R. W. Peterson. 1979. "Geotechnical Properties of 0il Shale Retorted by the PARAHO and Tosco Processes, "Final Report to the U.S. Bureau of Mines under Contract H0262064, prepared by Waterways Experiment Station, Vicksburg, Mississippi. 


\section{DISTRIBUTION}

No. of

Copies

OFFSITE

27 DOE Technical Information Center

Edward Bates

Industrial Environ. Research Lab

Extraction Tech. Branch

U.S. Environ. Protection Agency

Cincinnati, $\mathrm{OH} 45268$

Willard R. Chappell

Campus Box 136

University of Colorado

1100 14th Street

Denver, CO 80202

R. Merril Coomes

TOSCO Corporation

10100 Santa Monica Blvd.

Los Angeles, CA 90067

J. Phyllis Fox

J. Phyllis Fox Consulting Serv.

1988 California

Berkeley, CA 94703

Ralph E. Franklin

U.S. Department of Energy

ER-75 GTN

Washington, DC 20545

James Godlove

White River Shale 0 il Corp.

115 South Main Street

Suite 500 Prudential Bldg.

Salt Lake City, UT 84111

Lawrence B. Gratt

IWG Corp.

975 Hornblend Street

Suite C

San Diego, CA 92109
No. of

Copies

Arthur Hartstein

U.S. Department of Energy

Office of Fossil Energy

FE-34, GTN

Washington, DC 20545

Robert N. Heistand

Anvil Points, Box A

Rifle, Co 81650

Jane King

American Petroleum Institute

2101 L Street, N.W.

Washington, DC 20037

Helen M. McCammon

Ecological Research Division

EV-34

E-201 GTN

Office of Energy Research

Washington, DC 20545

Dennis Miller

National Research Council

2101 Constitution Ave., N.W.

Room JH 734

Washington, DC 20418

Glenn Miller

Area 0 il Shale Supervisor's office

131 North 6th Street

Suite 300

Grand Junction, CO 81501

Kathy Petersen

Center for Environ. Sciences

University of Colorado

1100 14th Street

Campus Box 136

Denver, C0 80202 
No. of

Copies

Edward Redente

Colorado State University Department of Range Sciences

Ft. Collins, CO 80523

Carlton B. Scott

Union 0il Company

461 S. Boylston Street

Los Angeles, CA 90017

Dave Shelton, Director

Colorado Mined Land

Rec lamation

1313 Sherman Street

Room 423

Denver, CO 80203

G. C. Slawson

Rio Blanco Oil Shale Company

2851 South Parker Road

Suite 500

Aurora, CO 80014

Russel Tait

ESSO, Australia Limited

70 Goondoon Street

Gladstone, Queens land

Australia

Allen Verstuyft

Chevron Shale 0il Company

Great West Plaza, Tower 2

1625 Broadway

Suite 2150

Denver, CO 80202

Jim Westhoff

Laramie Energy Technical Center

University Station

P. 0. Box 3395

Laramie, WY 82071
No. of

Cop ies

ONSITE

DOE Richland Operations Office

H. E. Ransom

Marine Research Laboratory (Sequim)

R. L. Schmidt

50 Pacific Northwest Laboratory

F. W. Bond

K. E. Byers (4)

M. E. Dodson

A. R. Felmy

J. S. Fruchter

T. R. Garland

T. E. Gates (5)

G. W. Gee (10)

D. C. Girvin

A. J. Haverfield

P. R. Heller

$E$. A. Jenne

K. M. Krupka

D. E. Oleson

R. G. Riley

J. E. Rogers

J. A. Stott lemyre

N. M. Sherer

W. L. Temp leton

R. E. Wildung (5)

W. R. Wiley

B. E. Vaughan

Z. M. Zachara

Technical

Information (5)

Publishing Coordination (BE)(2) 